\section{OPEN ACCESS}

Edited by:

Felipe Klein Ricachenevsky, Universidade Federal de Santa Maria

Reviewed by:

Kazuo Nakashima,

Japan International Research Center

for Agricultural Sciences, Japan

Alexander Arthur Theodore Johnson,

University of Melbourne, Australia

*Correspondence:

Fernando Carlos Gómez-Merino

fernandg@colpos.mx

'These authors have contributed equally to this work

Specialty section:

This article was submitted to

Plant Nutrition,

a section of the journal

Frontiers in Plant Science

Received: 06 July 2016 Accepted: 12 January 2017

Published: 14 February 2017

Citation:

Moreno-Alvarado $M$,

García-Morales S, Trejo-Téllez LI,

Hidalgo-Contreras JV and Gómez-Merino FC (2017) Aluminum

Enhances Growth and Sugar

Concentration, Alters Macronutrient Status and Regulates the Expression of NAC Transcription Factors in Rice.

Front. Plant Sci. 8:73.

doi: 10.3389/fp/s.2017.00073

\title{
Aluminum Enhances Growth and Sugar Concentration, Alters Macronutrient Status and Regulates the Expression of NAC Transcription Factors in Rice
}

\begin{abstract}
Marcos Moreno-Alvarado ${ }^{1 \dagger}$, Soledad García-Morales ${ }^{1,2 \dagger}$, Libia Iris Trejo-Téllez ${ }^{3}$, Juan Valente Hidalgo-Contreras ${ }^{1}$ and Fernando Carlos Gómez-Merino ${ }^{1 *}$
\end{abstract}

${ }^{1}$ Biotechnology, Colegio de Postgraduados Campus Córdoba, Amatlán de los Reyes, Mexico, ${ }^{2}$ Plant Biotechnology, CONACYT-CIATEJ, El Bajío del Arenal, Zapopan, Mexico, ${ }^{3}$ Soil Science-Plant Nutrition, Colegio de Postgraduados Campus Montecillo, Montecillo, Mexico

Aluminum (Al) is a beneficial element for some plant species, especially when used at low concentrations. Though some transcription factors are induced by exposure to this element, no data indicate that $\mathrm{Al}$ regulates the expression of NAC genes in rice. In this study we tested the effect of applying $200 \mu \mathrm{M}$ Al on growth, chlorophyll, amino acids, sugars, macronutrient concentration and regulation of NAC transcription factors gene expression in 24-day-old plants of four rice (Oryza sativa ssp. indica) cultivars: Cotaxtla, Tres Ríos, Huimanguillo and Temporalero, grown hydroponically under greenhouse conditions. Twenty days after treatment, we observed that Al enhanced growth in the four cultivars studied. On average, plants grown in the presence of Al produced 140\% more root dry biomass and were $30 \%$ taller than control plants. Cotaxtla and Temporalero showed double the root length, while Huimanguillo and Cotaxtla had three times more root fresh biomass and 2.5 times more root dry biomass. Huimanguillo plants showed 1.5 times more shoot height, while Cotaxtla had almost double the root dry biomass. With the exception of Tres Ríos, the rest of the cultivars had almost double the chlorophyll concentration when treated with Al, whereas amino acid and proline concentrations were not affected by Al. Sugar concentration was also increased in plants treated with $\mathrm{Al}$, almost 11-fold in comparison to the control. Furthermore, we observed a synergic response of $\mathrm{Al}$ application on $\mathrm{P}$ and $\mathrm{K}$ concentration in roots, and on $\mathrm{Mg}$ concentration in shoots. Twenty-four hours after Al treatment, NAC transcription factors gene expression was measured in roots by quantitative RT-PCR. Of the 57 NAC transcription factors genes primer-pairs tested, we could distinguish that 44\% (25 genes) showed different expression patterns among rice cultivars, with most of the genes induced in Cotaxtla and Temporalero plants. Of the 25 transcription factors up-regulated, those showing differential expression mostly belonged to the NAM subfamily (56\%). We conclude that Al improves growth, increases sugar concentration, $P$ and $K$ concentrations in roots, and Mg concentration in shoots, and report, for the first time, that Al differentially regulates the expression of NAC transcription factors in rice.

Keywords: Oryza sativa, beneficial elements, aluminum, amino acid, nutrient concentration, NAM subfamily, qRT-PCR 


\section{INTRODUCTION}

Aluminum comprises approximately 7\% of the Earth's crust, making it the third most abundant element (after oxygen and silicon) and the most abundant metal on Earth (Matsumoto and Motada, 2012; Matsumoto et al., 2015). Aluminum, which occurs naturally as a free metal, is so chemically reactive that native specimens are rare and limited to reducing environments. Its biological functions are complex and have been largely associated with physiological disorders in plants (Matsumoto and Motada, 2012). Indeed, Al is a major growth-limiting factor in acid soil. It is estimated that approximately $30-40 \%$ of arable land and up to $70 \%$ of the world's potentially arable land is occupied by acid soils. In these soils, $\mathrm{Al}$ is solubilized into ionic forms, especially when the soil $\mathrm{pH}$ falls to lower than 5 . Under such conditions, most $\mathrm{Al}$ exists as the octahedral hexahydrate, $\mathrm{Al}\left(\mathrm{H}_{2} \mathrm{O}\right)_{6}^{3+}$, often abbreviated as $\mathrm{Al}^{3+}$, which is believed to be the most toxic $\mathrm{Al}$ form (Kochian et al., 2005; Ma and Ryan, 2010). Sade et al. (2016) have recently reviewed toxicity and tolerance of $\mathrm{Al}$ in plants. Nevertheless, $\mathrm{Al}$ has also been referred to as a beneficial element. Especially in plants native to tropical regions where acid soils are common, Al stimulates plant growth and enhances $\mathrm{P}$ uptake (Osaki et al., 1997). In tea (Camellia sinensis) and Indian rhododendron (Melastoma malabathricum), Al induces plant growth, activates antioxidant responses and improves nutrient status (Ghanati et al., 2005; Watanabe et al., 2005). In alfalfa (Medicago sativa), Al enhances root growth (Zhang et al., 2007), whereas in common bean (Phaseolus vulgaris) it improves root and shoot growth as well as antioxidant activity (Du et al., 2010) and in maize (Zea mays) it stimulates leaf growth (Wang et al., 2015). In rice (Oryza sativa), Al stimulates growth (Osaki et al., 1997), root elongation (Famoso et al., 2011), shoot height and chlorophylls as well as carotenoids concentrations (Nhan and Hai, 2013).

By definition, plants that accumulate $>1 \mathrm{mg} \mathrm{g}^{-1} \mathrm{Al}$ (in dry biomass weight) are considered Al-hyperaccumulators (Jansen et al., 2002). These plants are able to use Al to stimulate growth and trigger mechanisms against herbivores, as occurs with tall fescue (Festuca arundinacea) (Potter et al., 1996). A possible explanation for this defense response in tall fescue is that $\mathrm{Al}$ deposits form an olfactory or tactile barrier, preventing female insects from laying their eggs, which might account for lower numbers of grubs in treated plots (Potter et al., 1996).

According to Pilon-Smits et al. (2009), the beneficial effects of $\mathrm{Al}$ in plants are associated with the promotion of growth, activation of antioxidant mechanisms, and increased $\mathrm{P}$ availability and decreased Fe toxicity. Consequently, Al may be used as a biostimulant to promote growth and productivity in crop plants, especially when used at low concentrations. Nevertheless, studies on the beneficial effects of $\mathrm{Al}$ on plant metabolism are relatively scarce, in comparison to those related to the toxic effects and tolerance mechanisms of plants exposed to this metal (Hajiboland et al., 2013a).

According to recent reports, increasing evidence points to an important role played by transcription factors in $\mathrm{Al}$ signal perception and transduction (Yokosho and Ma, 2015). The $\mathrm{C} 2 \mathrm{H} 2$-type zinc-finger transcription factor STOP1 (sensitive to proton rhizotoxicity 1 ) is not sensitive to either to $\mathrm{Al}$ or low pH (Liu et al., 2009; Sawaki et al., 2009). STOP2, a homolog of STOP1 in Arabidopsis, is regulated by the STOP1 protein (Kobayashi et al., 2014) in response to acidic media and Al. The gene ART1 (Al resistance transcription factor 1 ) is another $\mathrm{C} 2 \mathrm{H} 2$-type zinc-finger transcription factor found in rice (Yamaji et al., 2009) that regulates the expression of at least 31 genes such as STAR1, STAR2, Nrat1, OsALS1, and OsMGT1, which are involved in $\mathrm{Al}$ transport. In addition, ART1 activates the transcription of the genes OsCDT3 and OsFRDL4 involved in citrate secretion in response to $\mathrm{Al}$ (Yokosho and Ma, 2015). The proteins STOP1 and ART1 regulate only two genes in common (AtMATE/OsFRDL4 and ALS3/STAR2), which may suggest that such proteins are involved in different Al-tolerance pathways. The WRKY46 transcription factor belongs to the family WRKY, and is a negative regulator of the AtALMT1 gene, which in turn is a key regulator of $\mathrm{Al}$ tolerance in Arabidopsis (Ding et al., 2013). Finally, ASR5 (Abscisic acid, stress and ripening 5) is a transcription factor found in rice, closely related to Al tolerance (Arenhart et al., 2014). Nevertheless, there are no reports on the involvement of NAC transcription factors in plant responses to $\mathrm{Al}$ exposure. NAC is an acronym derived from the names of the three genes first described as containing the domain, namely NAM (no apical meristem), ATAF1,2 (Arabidopsis transcription activation factor), and CUC2 (cup-shaped cotyledon). These proteins are plant-specific transcription factors reported to be involved in developmental and growth processes, as well as in the coordination of responses in plant cells to environmental cues of both a biotic and abiotic nature (Nuruzzaman et al., 2013; Nakashima et al., 2014; Hong et al., 2016).

Rice is one of the most Al-tolerant crop species in the world. It can tolerate two- to five-fold higher Al levels than wheat, sorghum or maize (Famoso et al., 2010; Arenhart et al., 2014). Herein, we determined the effect of $\mathrm{Al}$ on plant growth, amino acids, proline, soluble sugars and macronutrients concentrations in roots and shoots of four Mexican rice cultivars (Cotaxtla, Tres Ríos, Huimanguillo, and Temporalero), as well as the expression profiling of NAC genes transcription factors in roots. We observed that $\mathrm{Al}$ increased root and shoot growth, as well as soluble sugars in leaves and $\mathrm{P}$ in roots. Interestingly, we report for the first time, to our knowledge, the induction of NAC gene expression in Al-treated rice plants.

\section{MATERIALS AND METHODS Rice Cultivars and Experimental Conditions}

We evaluated four Mexican rice cultivars (ssp. indica): Cotaxtla, Tres Ríos, Huimanguillo and Temporalero, provided by the National Rice Germplasm Bank housed in the National Institute for Forestry, Agriculture and Livestock Research (INIFAP) located in Zacatepec, Mexico (18 $39^{\prime} \mathrm{NL}, 99^{\circ} 12^{\prime} \mathrm{WL}, 910$ masl).

For germination experiments, seeds were surface sterilized with $70 \%$ ethanol for $7 \mathrm{~min}$, and soaked for $30 \mathrm{~min}$ in a solution containing 3\% sodium hypochlorite and a drop of Tween-20. Subsequently, seeds were rinsed 5 times with distilled water, 
dried on filter paper under a fume hood and then sown in $500 \mathrm{~mL}$ flasks containing MS medium (Murashige and Skoog, 1962), supplemented with $3 \%$ sucrose (w/v) and solidified with $0.8 \%$ agar. Flasks were incubated in darkness at $28^{\circ} \mathrm{C}$ for $72 \mathrm{~h}$. Subsequently, plantlets were grown under a day-length of $12 \mathrm{~h}$ at $26 / 22^{\circ} \mathrm{C}$ (day/night), $70 \%$ humidity and $700 \mu \mathrm{mol}$ $\mathrm{m}^{-2} \mathrm{~s}^{-1}$ light intensity. Eleven days after germination, plants were transferred to $12 \mathrm{~L}$ trays containing Yoshida nutrient solution, which contained $1.43 \mathrm{mM} \mathrm{NH}_{4} \mathrm{NO}_{3}, 1.00 \mathrm{mM} \mathrm{CaCl}$ $2 \mathrm{H}_{2} \mathrm{O}, 1.64 \mathrm{mM} \mathrm{MgSO} 47 \mathrm{H}_{2} \mathrm{O}, 0.13 \mathrm{mM} \mathrm{K}_{2} \mathrm{SO}_{4}, 0.32 \mathrm{mM}$ $\mathrm{NaH}_{2} \mathrm{PO}_{4} .2 \mathrm{H}_{2} \mathrm{O}$, $1.00 \mathrm{mM}$ Fe-EDTA, $7.99 \mu \mathrm{M} \mathrm{MnCl} 24 \mathrm{H}_{2} \mathrm{O}$, $0.15 \mu \mathrm{M} \mathrm{ZnSO} 4 \quad 7 \mathrm{H}_{2} \mathrm{O}, 0.15 \mu \mathrm{M} \mathrm{CuSO}_{4} 5 \mathrm{H}_{2} \mathrm{O}, 0.075 \mu \mathrm{M}$ $\left(\mathrm{NH}_{4}\right)_{6} \mathrm{Mo}_{7} \mathrm{O}_{24} 4 \mathrm{H}_{2} \mathrm{O}$ and $1.39 \mu \mathrm{M} \mathrm{H}_{3} \mathrm{BO}_{3}$ (Yang et al., 1994). The $\mathrm{pH}$ in the solution was adjusted to 5.5. Thirteen days after transplanting, the nutrient solution was completely replaced and rice plants were grown under control conditions or subjected to $\mathrm{Al}$ treatment $(200 \mu \mathrm{M} \mathrm{AlCl} 3$ at $\mathrm{pH} 4.2)$ for 20 days. The hydroponic solution was replaced every 5 days, and it was not oxygenated since rice can cope with low (hypoxia) or absent oxygen (anoxia) (Yamauchi et al., 2000; Joshi and Kumar, 2012). These experiments were carried out in a greenhouse under the aforementioned environmental conditions.

\section{Sample Collection}

In order to determine chlorophyll, amino acids, proline and macronutrients concentrations, plants were harvested 20 days after treatment application. To carry out the expression profiling analyses of NAC genes, plants were sampled before treatment application and $24 \mathrm{~h}$ after exposure to $\mathrm{Al}$; immediately after sampling, plants were rinsed with distilled water, separated into roots and shoots, frozen in liquid nitrogen and then stored at $-80^{\circ} \mathrm{C}$ until RNA extraction.

\section{Plant Growth and Biomass Production}

Plant growth and biomass production were determined 20 days after treatment applications. Plant height was estimated measuring from the shoot base to the tip of the flag leaf. Root length was measured from the shoot base to the tip of the longest root hair. Dry biomass weight was determined $48 \mathrm{~h}$ after drying samples (roots and shoots) at $70^{\circ} \mathrm{C}$ in a forced-air drying oven (Riossa HCF-125D; Monterrey, N.L., Mexico).

\section{Quantification of Chlorophylls and Total Free Amino Acids}

Chlorophylls ( $a, b$, and total) and total free amino acid concentrations in leaf were determined by ethanolic extraction according to Geiger et al. (1998). We sampled the 2nd and 3 rd youngest leaves and samples were immediately frozen in liquid nitrogen and then stored at $-80^{\circ} \mathrm{C}$, until analyzed. From those samples, $20 \mathrm{mg}$ of fresh tissue were taken and mashed with pestle and mortar in liquid nitrogen. We carried out two extractions with $80 \%$ ethanol and a third one with $50 \%$ ethanol. During the three extractions, samples were incubated at $80^{\circ} \mathrm{C}$ for $20 \mathrm{~min}$, and then the three extracts were mixed. For chlorophyll quantification, we took $325 \mu \mathrm{L}$ of the final extract and mixed it with $850 \mu \mathrm{L} 98 \%$ ethanol, and recorded chlorophyll concentrations at 645 and $665 \mathrm{~nm}$. Chlorophyll quantification was calculated using the following formulas (where FBW is fresh biomass weight):

$$
\begin{gathered}
\text { Chlorophyll } a \text { concentration }\left(\mu \mathrm{g} \mathrm{mg}^{-1} \mathrm{FBW}\right)=(5.46 \\
\times \text { Absorbance } 665 \mathrm{~nm})-(2.16 \times \text { Absorbance } 645 \mathrm{~nm}) \\
\text { Chlorophyll } b \text { concentration }\left(\mu \mathrm{g} \mathrm{mg}{ }^{-1} \mathrm{FBW}\right)=(9.67 \\
\times \text { Absorbance } 645 \mathrm{~nm})-(3.04 \times \text { Absorbance } 665 \mathrm{~nm}) \\
\text { Total Chlorophyll concentration }\left(\mu \mathrm{g} \mathrm{mg}^{-1} \mathrm{FBW}\right)= \\
\text { chlorophyll } a+\text { chlorophyll } b
\end{gathered}
$$

We then determined total free amino acid concentrations by the ninhydrin method (Moore and Stein, 1954). We took $250 \mu \mathrm{L}$ of the final extract, added $250 \mu \mathrm{L}$ of the sodium citrate [citric acid $(16 \mathrm{mM})+$ sodium citrate $(34 \mathrm{mM}), \mathrm{pH}$ 5.2] - ascorbic acid ( $0.2 \%$ in sodium citrate solution) buffer solution, and 500 $\mu \mathrm{L}$ ninhydrin (1\% in $70 \%$ ethanol). Subsequently, samples were incubated in a water bath at $95^{\circ} \mathrm{C}$ for $20 \mathrm{~min}$. We used leucine (10 $\mathrm{mM}$ in $70 \%$ ethanol) to construct the standard curve, and calculated the amino acid concentrations at $570 \mathrm{~nm}$ absorbance.

\section{Quantification of Free Proline and Total Soluble Sugars}

Total free proline was determined in rice plant shoots according to Bates et al. (1973). We used $50 \mathrm{mg}$ of previously lyophilized and crushed tissue. Then we carried out a first extraction by macerating the samples with $5 \mathrm{~mL} \mathrm{3 \%}$ sulfosalicylic acid, and filtering the sample with filter paper No. 4. Subsequently, we mixed $2 \mathrm{~mL}$ of ninhydrin solution $(2.5 \% \mathrm{w} / \mathrm{v}$ contained in the solution of $60 \%$ concentrated acetic acid and $40 \%$ phosphoric acid $6 \mathrm{M}$ ), plus $2 \mathrm{~mL}$ concentrated glacial acetic acid and $2 \mathrm{~mL}$ of the extract of each sample. The mixture was incubated in a water bath at $95^{\circ} \mathrm{C}$ for $40 \mathrm{~min}$, and the reaction was stopped by placing samples on ice. After the reaction, $4 \mathrm{~mL}$ toluene were added to each sample, mixed briefly (vortex) and incubated at room temperature for $15 \mathrm{~min}$. For proline quantification, we constructed a standard curve using L-proline $\left(400 \mathrm{nM} \mathrm{mL}^{-1}\right)$ and the corresponding absorbance was measured at $520 \mathrm{~nm}$. Quantification of total soluble sugars in leaves was determined according to the protocol described by Bailey (1958). Shoot tissues were lyophilized, powdered and weighed. Later, extraction was performed using $50 \mathrm{~mL} 80 \%$ ethanol at constant boiling on a thermal shaker with occasional stirring. The supernatant was filtered and the total volume was gauged to $10 \mathrm{~mL}$ using $80 \%$ ethanol. One $\mathrm{mL}$ of the final extract was taken, placed on a 50 $\mathrm{mL}$ glass tube and $5 \mathrm{~mL}$ anthrone $(0.4 \%$ in concentrated sulfuric acid) were added; during the process samples were kept on ice. Afterwards, samples were incubated in a water bath at $95^{\circ} \mathrm{C}$ for $15 \mathrm{~min}$; the reaction was stopped by placing samples on ice. For soluble sugars quantification, we constructed a standard curve using sucrose $(0.015 \% \mathrm{w} / \mathrm{v})$ and measurements were carried out at an absorbance of $600 \mathrm{~nm}$.

\section{Nutrient Concentrations}

Once samples were completely dried, they were ground, weighed and subjected to acidic digestion in a mixture of perchloric and nitric acids, according to the protocol described by Alcántar 
and Sandoval (1999). To determine concentrations of Al, P, K, $\mathrm{Ca}$, and $\mathrm{Mg}$ in plant tissues, extracts were analyzed using an inductively coupled plasma atomic emission spectrometer (ICPOES) (Agilent ICP-AES 725-ES; Victoria, Australia). Nitrogen concentrations were quantified using the Semimicro-Kjeldahl method as described by Bremner (1996), using a catalytic mixture and adding salicylic acid dissolved in concentrated sulfuric acid for the digestion.

\section{RNA Extraction and cDNA Synthesis}

RNA extraction was carried out with $50 \mathrm{mg}$ plant tissue, using the SV total RNA Isolation System kit (Promega; Madison, WI, USA), according to the manufacturer's protocol, which includes a DNAse I treatment. RNA concentration was measured in a NanoDrop 2000 UV-Vis spectrometer (Thermo Scientific; Waltham, MA, USA). RNA integrity was assessed by electrophoresis on $1 \%(\mathrm{w} / \mathrm{v})$ agarose gels. In all of the samples, $\mathrm{A}_{260} / \mathrm{A}_{280}$ relation values were equal or higher than 1.8 and $\mathrm{A}_{260} / \mathrm{A}_{230}$ relations were equal or higher than 2.1, meaning that the RNA had good quality for further analyses.

For reverse transcription we used 3.5-5.0 $\mu \mathrm{g}$ total RNA, using the oligo-dT primer for the cDNA first strand synthesis and the enzyme SuperScript III ${ }^{\mathrm{TM}}$ RT (Invitrogen; Carlsbad, CA, USA), in a total reaction volume of $20 \mu \mathrm{L}$, according to the manufacturer's protocol.

\section{Primers for RT-PCR Analysis}

Primers pairs used in this study were those previously reported by García-Morales et al. (2014) and Caldana et al. (2007). We also tested the expression of the following NAC genes: OsNAC6 (Nakashima et al., 2007), OsNAC5 (Sperotto et al., 2009), and OsNAC10 (Jeong et al., 2010). As positive controls, we evaluated the expression of two genes previously reported as Al-responsive: sensitive to Al rhizotoxicity1 (STAR1) and abscisic acid, stress, and ripening 5 (ASR5) (Huang et al., 2009; Arenhart et al., 2016). Additionally, we measured the expression of the following transcription factors involved in various plant responses to environmental stress: OsDREB1A (Kim et al., 2010), OsDREB2A and OsDREB2B1 (Matsukura et al., 2010), TRAB1 (Yang et al., 2011), OsbZIP72 (Lu et al., 2009), and OsRAN2 (Zang et al., 2010). (Supplementary Material S1). Housekeeping genes tested in this study were Actin (Os03g50890), Actin 1 (Os05g36290), $\beta$ tubulin (Os01g59150), and Elongation factor $1 \alpha$ (Os30g55270). Gene-stability measure $(M)$ of reference genes was determined according to Vandesompele et al. (2002) and we selected the most stable reference gene (with the lowest $M$-value) for the calculation of relative expression of NAC genes (Supplementary Material S2).

\section{Real Time RT-PCR}

Real time RT-PCR was carried out in an ABI Prism 7900HT (Applied Biosystems; Foster City, CA, USA) sequence detection system, using Power SYBR ${ }^{\circledR}$ Green PCR Master Mix 2X (Life Technologies; Carlsbad, CA, USA), according to the manufacturer's protocol. The final concentration of each primer was $250 \mathrm{nM}$ and $20 \mathrm{ng}$ of cDNA in the final volume of $20 \mu \mathrm{L}$ were used. The PCR reaction conditions were as follows: $50^{\circ} \mathrm{C}$ for $2 \mathrm{~min}, 95^{\circ} \mathrm{C}$ for $10 \mathrm{~min}, 40 \mathrm{cycles}$ at $95^{\circ} \mathrm{C}$ for $15 \mathrm{~s}$ and $60^{\circ} \mathrm{C}$ for $1 \mathrm{~min}$. The dissociation curve was obtained after the cycle of the PCR reaction at $95^{\circ} \mathrm{C}$ for $15 \mathrm{~s}$ followed by a constant increase $(2 \%)$ between 60 and $95^{\circ} \mathrm{C}$. For each PCR reaction, a dissociation stage was included in order to readily assess the homogeneity of the PCR products, including the presence of primer-dimers, thereby determining the specificity of the PCR reaction (Schmittgen and Livak, 2008). As reference gene we used Actin (Os03g50890) in order to normalize the expression of the analyzed genes. All reactions were performed with three technical replicates.

Relative expression of the genes of interest was calculated using the $2^{-\Delta \Delta \mathrm{Ct}}$ method (Schmittgen and Livak, 2008). Accordingly, expression data were normalized by subtracting the mean reference gene $C_{T}$ value from its $C_{T}$ value $\left(\Delta C_{T}\right)$. The

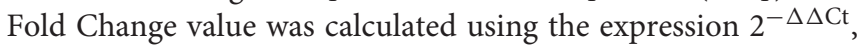
where $\Delta \Delta \mathrm{C}_{\mathrm{T}}$ represents $\Delta \mathrm{C}_{\mathrm{T} \text { condition of interest }}-\Delta \mathrm{C}_{\mathrm{T} \text { control }}$. Results were transformed to $\log _{2}$ scale. In accordance with Le et al. (2011) and García-Morales et al. (2014), and considering the biological significance of the differential expression in this study, we adopted a cut-off value of two-fold when analyzing $\mathrm{Al}$ induction or repression. The expression levels were designated as "induced" (Fold Change $\geq+2$ ) or "repressed" (Fold Change $(\leq-2)$ only if such differences met the above criteria and passed the Fisher LSD test (Le et al., 2011; García-Morales et al., 2014).

\section{Statistical Analysis}

Results are means \pm standard error of at least four independent samples per cultivar and treatment. Data were analyzed using the statistical software SAS (SAS Institute, 2004). We carried out an analysis of variance by multifactorial ANOVA, using treatment and cultivar as independent factors. Means comparison was done using Tukey's test with a significance value of $95 \%(P \leq 0.05)$, in order to determine significant differences. In order to obtain mean comparisons among rice cultivars regarding NAC gene expression, the Fisher LSD $(\mathrm{P} \leq 0.05)$ test was used.

\section{RESULTS}

\section{Al Enhances Root and Shoot Growth}

In a preliminary experiment, we tested the effect of $0,25,50$, 100,200 , and $400 \mu \mathrm{M} \mathrm{Al}$ on the growth and development of cultivars Cotaxtla, Tres Ríos, Huimanguillo, and Temporalero. The stimulant effect of $\mathrm{Al}$ on plant growth was observed in all $\mathrm{Al}$ concentrations tested, though negative effects of $400 \mu \mathrm{M} \mathrm{Al}$ on root growth and tiller formation in Cotaxtla and Tres Ríos plants were also detected (Supplementary Material S3). Based on those findings, we decided to perform further analysis by comparing 0 (control) and $200 \mu \mathrm{M} \mathrm{Al}$. Other studies aimed at detecting toxic effects of $\mathrm{Al}$ on plant physiology have tested $\mathrm{Al}$ concentrations higher than $200 \mu \mathrm{M}$. In rice, Famoso et al. $(2010,2011)$ evaluated 540 and $1290 \mu \mathrm{M} \mathrm{AlCl}_{3}$, whereas Arenhart et al. (2014) tested $450 \mu \mathrm{M} \mathrm{AlCl}$. As well, Roselló et al. (2015) applied $500 \mu \mathrm{M}$ $\mathrm{AlCl}_{3}$ in rice, while Cançado et al. (2008) applied up to $283 \mu \mathrm{M}$ of $\mathrm{AlK}_{3}\left(\mathrm{SO}_{4}\right)_{3}$ to maize plants.

In this study, we grew the Mexican rice cultivars Cotaxtla, Tres Ríos, Huimanguillo, and Temporalero hydroponically in Yoshida 
nutrient solution under greenhouse conditions. Treatments without and with $\mathrm{Al}$ ( 0 and $200 \mu \mathrm{M} \mathrm{AlCl}$, respectively) were applied to 24-day-old plants for 20 days. We found that plant growth was stimulated by $\mathrm{Al}$ (Figure 1). Indeed, plant height increased approximately $30 \%$ in Al-treated plants in comparison to control plants. Interestingly, Huimanguillo plants increased $59 \%$ in height when treated with the metal in the nutrient solution. Cotaxtla and Tres Ríos showed an increase of 27 and $26 \%$, respectively, while Temporalero displayed the lowest gain, with only $18 \%$ in Al-treated plants in comparison to the control. Moreover, plants exposed to Al promoted tillering (Figure 1B).

A more evident beneficial effect of $\mathrm{Al}$ was observed in root growth. On average, the four cultivars increased root length by $90 \%$ when treated with $\mathrm{Al}$, in comparison with the control. Cotaxtla and Temporalero plants showed almost double the root length, whereas Tres Ríos increased this value by $86 \%$ and Huimanguillo by 69\% (Figure 1C). Surprisingly, we could observe a higher number of roots in Al-treated plants, in comparison to control plants (Figure 1D).

\section{Al Induces Higher Fresh and Dry Biomass Production}

Aluminum enhanced biomass production in the four rice cultivars evaluated. In Cotaxtla plants, $\mathrm{Al}$ produced double the shoot fresh biomass, whereas it was 1.7 and 1.9 times higher in Tres Ríos and Huimanguillo, respectively; in Temporalero plants it was three times higher, in all cases, in comparison to the control (Figure 2A). A similar trend was observed in shoot dry biomass; consequently, Cotaxtla plants showed double the dry shoot biomass weight, 1.5 higher weights in Tres Ríos, and 1.7 in Huimanguillo and Temporalero, in comparison to control plants. Concerning this variable, we could also observe different responses among cultivars. Cotaxtla plants exhibited the highest biomass production, while the lowest production was recorded in Huimanguillo plants (Figure 2B).

Root fresh biomass weight was also increased by $\mathrm{Al}$ treatments; Al-treated Cotaxtla, Humanguillo, and Temporalero plants developed more than three times this weight in comparison to control plants, whereas Tres Ríos showed more than double the value in comparison to the control (Figure 2C). Similar results were observed for root dry biomass weight (Figure 2D), with stronger responses found in Cotaxtla and Temporalero treated with $\mathrm{Al}$.

\section{Aluminum Affects Chlorophyll Concentrations in Rice Leaves}

Chlorophyll $a, b$ and total chlorophyll concentrations increased as a consequence of $\mathrm{Al}$ treatment in all four cultivars tested, with
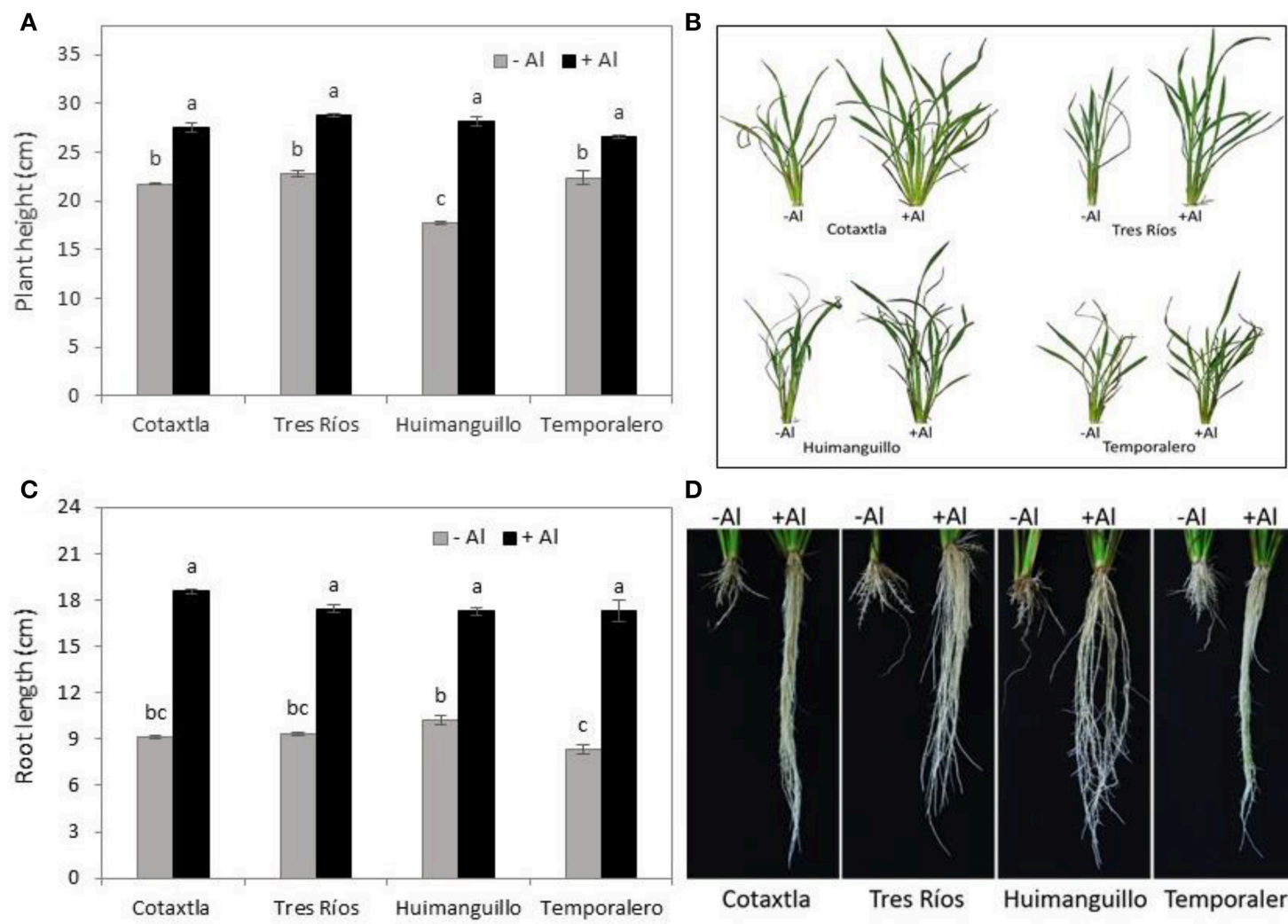

D

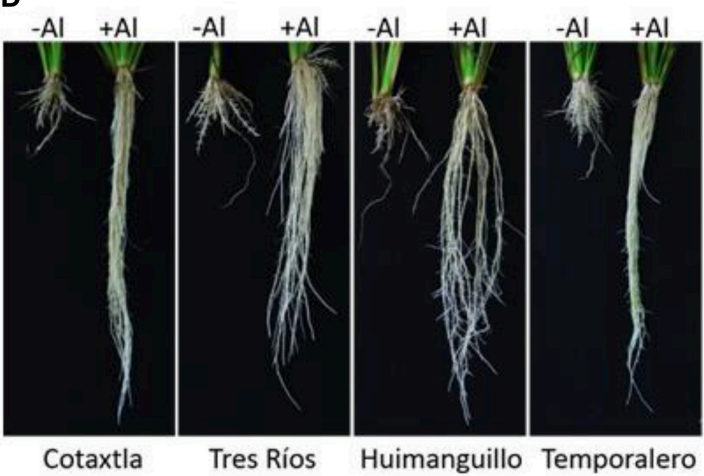

FIGURE 1 | Growth of rice plants in response to Al treatment. Plant height (A), root length (C) and photographic representation of shoot (B) and root (D) growth of rice plant cultivars Cotaxtla, Tres Ríos, Huimanguillo and Temporalero grown in the absence (-) or presence of $200 \mu \mathrm{M}$ Al (+) for 20 days. Values are means \pm standard error (SE) from at least five individual plants. Different letters above the column indicate significant differences (Tukey, $P \leq 0.05$ ). 

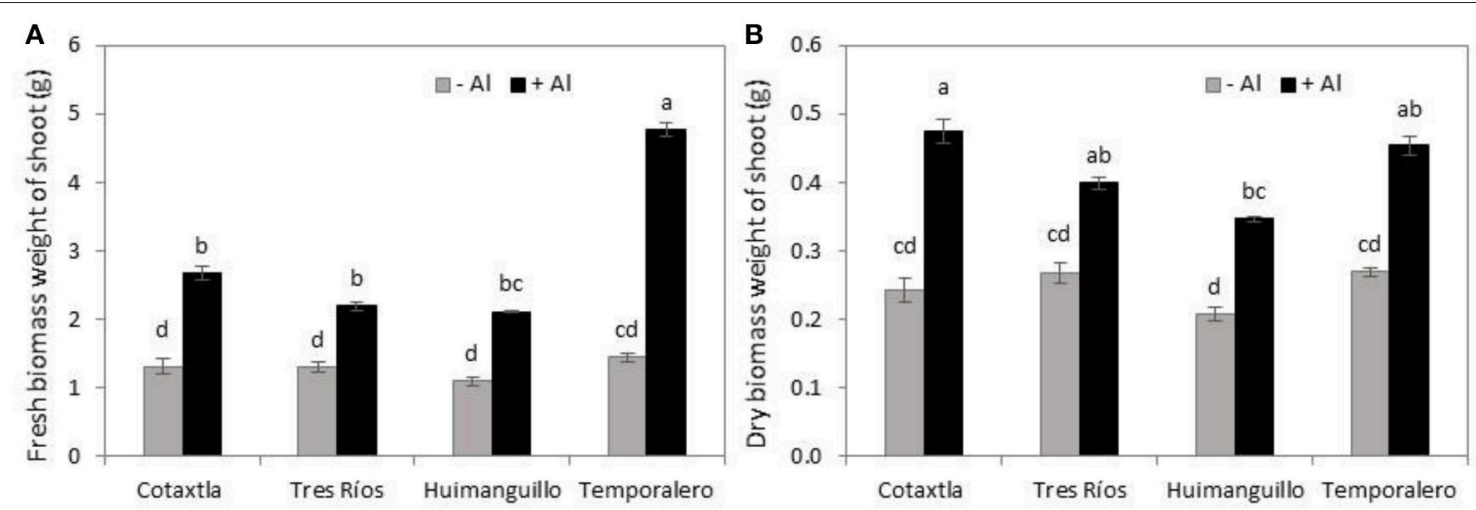

C

D
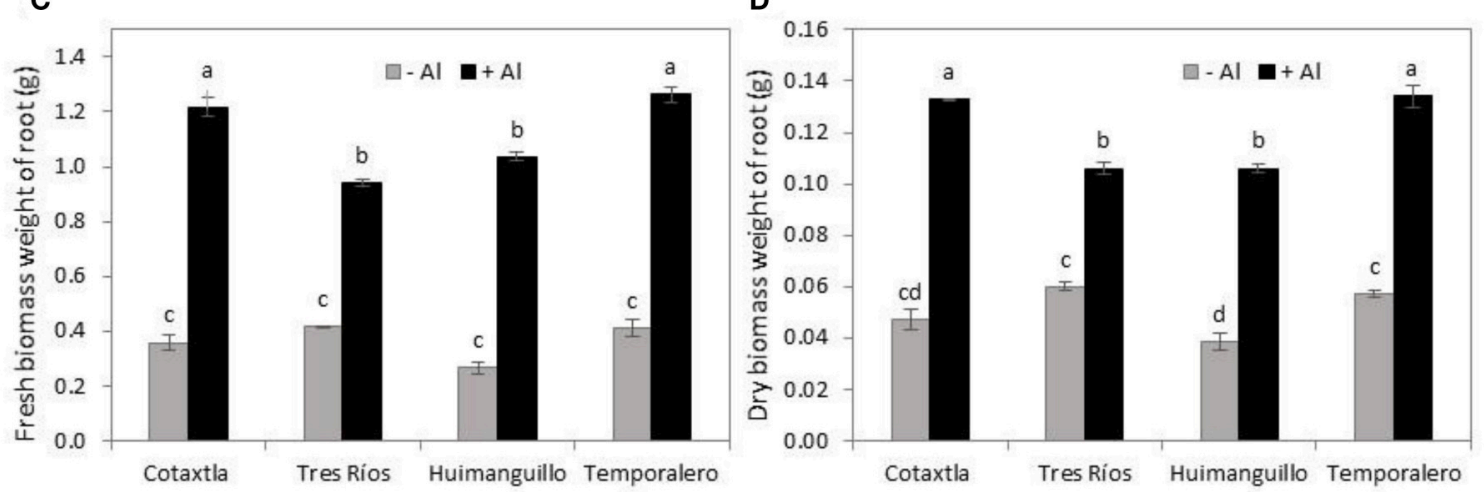

FIGURE 2 | Fresh and dry biomass production by rice plants in response to Al treatment. Fresh biomass weight of shoot (A) and root (C). Dry biomass weight of shoot (B) and root (D) of rice plant cultivars Cotaxtla, Tres Ríos, Huimanguillo and Temporalero grown in the absence ( - ) or presence of $200 \mu \mathrm{M}$ Al (+) for 20 days. Values are means \pm SE from at least five individual plants. Different letters above the column indicate significant differences (Tukey, $P \leq 0.05$ ).

the exception of Tres Ríos (Figure 3). In particular, in Al-treated Cotaxtla, Huimanguillo and Temporalero plants, chlorophyll $a$ concentrations were $50 \%$ higher than in the control. In Tres Ríos, chlorophyll a concentration was not affected by Al, though in Al-treated plants it was lower than in the other cultivars (Figure 3A). Chlorophyll $b$ concentration was higher in Altreated Cotaxtla and Huimanguillo plants, in comparison to control plants; in Temporalero plants there was no Al effect, whereas in Tres Ríos plants there was a reduction in chlorophyll $b$ in comparison to the control (Figure 3B). Regarding total chlorophyll concentrations, there was a similar behavior to that showed in chlorophyll $a$, with Tres Ríos being unaffected by $\mathrm{Al}$, whereas the rest of the cultivars showed a significant increase in Al-treated plants in comparison to the control (Figure 3C).

\section{Total Free Amino Acids and Proline Concentrations Are Not Affected by Al, but Soluble Sugars Are}

In order to investigate whether $\mathrm{Al}$ causes a stressful effect on the rice cultivars evaluated, we determined amino acids and proline concentrations in shoots. No differences were found between control and Al-treated plants concerning amino acid concentrations, in all four rice cultivars evaluated. Nonetheless, we did observe that Tres Ríos plants displayed the highest concentration of free amino acids in the control, while Cotaxtla and Temporalero had the lowest under the same environmental conditions (Figure 4A). Similarly, Al did not affect proline concentration in leaves of Cotaxtla, Tres Ríos, and Temporalero, whereas Huimanguillo plants displayed almost double the concentration of proline in the control in comparison to Altreated plants (Figure 4B).

Surprisingly, total soluble sugars concentration was significantly increased in Al-treated plants (Figure 4C). Indeed, in Cotaxtla plants, total soluble sugars concentration was nine-fold higher than that showed by the control, whereas in Tres Río it was two-fold increased, in Huimanguillo it was 25 times higher, and in Temporalero this increase was eight-fold higher than that showed by control plants (without $\mathrm{Al}$ ).

\section{Root and Shoot Aluminum and Macronutrient Concentrations Are Differentially Affected by Al Treatment}

Aluminum concentrations in root tissues were clearly increased in Al-treated plants; in control plants $\mathrm{Al}$ concentrations were nearly non-existent. When comparing cultivars, we observed that Temporalero (TM) showed a higher concentration of $\mathrm{Al}$ in roots, while Cotaxtla (CO) and Tres Ríos (TR) displayed a 

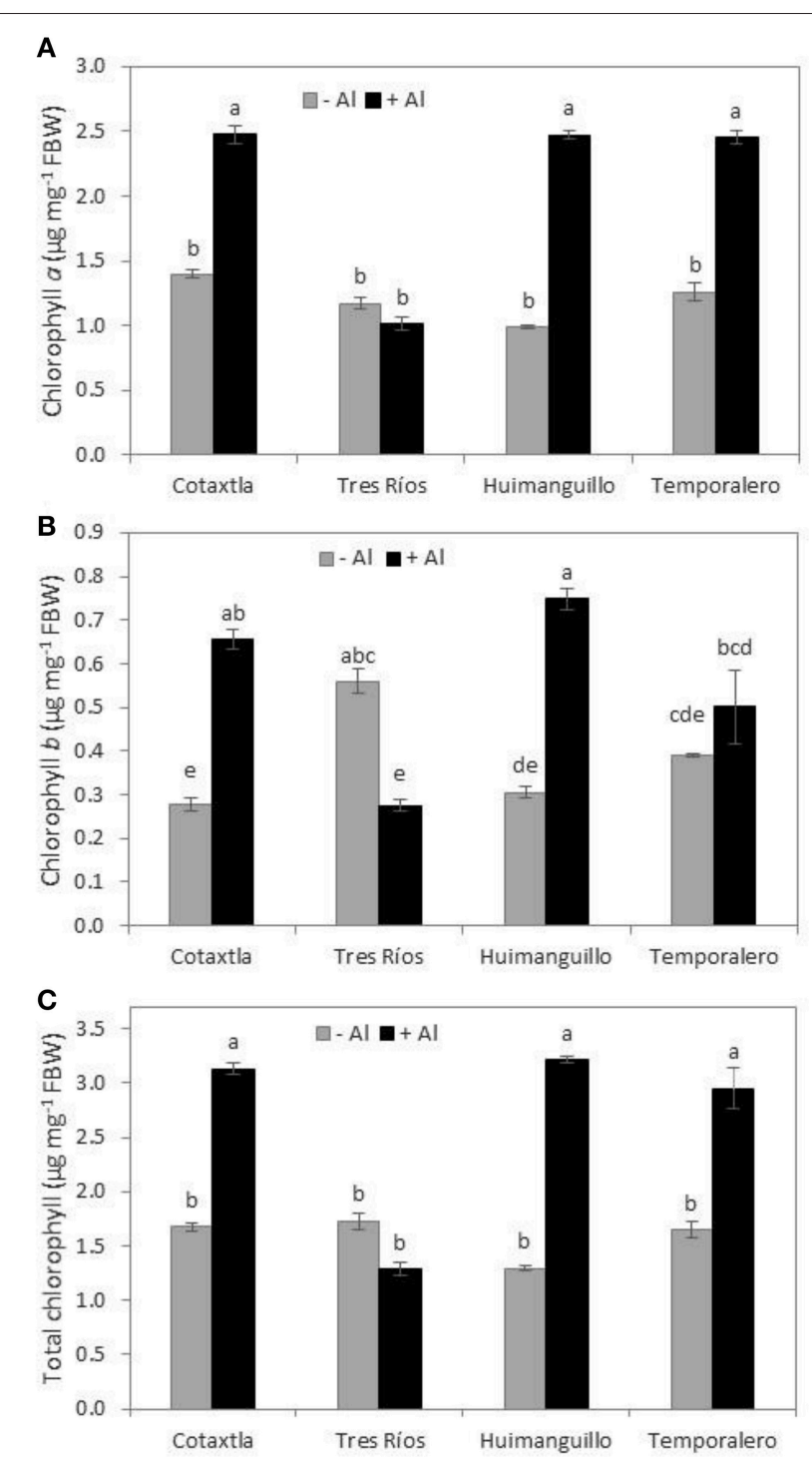

FIGURE 3 | Chlorophyll concentrations in rice plant leaves in response to Al treatment. Chlorophyll a (A), Chlorophyll b (B), and total Chlorophyll (C) in the 2nd and 3rd youngest leaves of rice plant cultivars Cotaxtla, Tres Ríos, Huimanguillo and Temporalero grown in the absence (-) or presence of 200 $\mu \mathrm{M} \mathrm{Al}(+)$ for 20 days. Values are means \pm SE from five individual plants. Different letters above the column indicate significant differences (Tukey, $P \leq$ 0.05). FBW, fresh biomass weight.

similar Al concentration in this tissue; finally, Huimanguillo (HU) registered the lowest $\mathrm{Al}$ concentration in roots (Figure 5A).

Regarding $\mathrm{N}$ concentrations we did not find any difference among cultivars, nor between $\mathrm{Al}$ treatments (Figure 5B). In roots all four cultivars exposed to $\mathrm{Al}, \mathrm{P}$ concentrations increased, in comparison to the control (-). Among cultivars, TM plants displayed the highest concentration of $\mathrm{P}$ and in $\mathrm{HU}$ roots the lowest concentration of this macronutrient was recorded (Figure 5C). A similar trend was observed regarding $\mathrm{K}$ concentration in roots, since three cultivars except TM increased K concentrations (Figure 5D).
As for $\mathrm{Ca}$, we only observed a reduction in roots of $\mathrm{CO}$ plants exposed to $\mathrm{Al}(+)$, in comparison to control plants (-), whereas in the rest of the cultivars evaluated we were unable to find significant effects of $\mathrm{Al}$ (Figure 5E).

Magnesium concentration in roots was similar in almost all cultivars except HU, where its concentration increased in response to $\mathrm{Al}$ treatment, in comparison to control plants (Figure 5F).

Aluminum and macronutrient concentrations in shoots are shown in Figure 6. As expected, Al concentration in shoots of the four cultivars evaluated increased in Al-treated plants in comparison to the control. Nevertheless, this increase was only significant for HU plants (Figure 6A).

Nitrogen concentration in shoots was not significantly affected by the treatments tested (Figure 6B). The same tendency was observed regarding $\mathrm{P}$ concentration, though TM plants showed the highest $\mathrm{P}$ concentration in both Al-treated and control plants (Figure 6C). Both K (Figure 6D) and Ca (Figure 6E) were not significantly affected by $\mathrm{Al}$, and differences among cultivars were also not evident. Interestingly, in TR and HU plants there was a significant increase in $\mathrm{Mg}$ concentration stimulated by $\mathrm{Al}$. However, TM showed the highest $\mathrm{Mg}$ concentrations both in Al-treated and control plants, whereas TR shoots recorded the lowest $\mathrm{Mg}$ concentration in the control (Figure 6F).

Nutrient solution was prepared with analytical-grade chemicals (purity $\geq 99 \%$ ). Nevertheless, control plants might have received traces of $\mathrm{Al}$, since we found small amounts of this element in shoots of those plants. Similar results have been reported by Marín-Garza et al. (2010), Hajiboland et al. (2013a), Gómez-Merino et al. (2014), and Roselló et al. (2015). Hajiboland et al. (2013b) attributed these responses to a possible content of $\mathrm{Al}$ in seeds and in the chemicals used to prepare the nutrient solution for control plants. Roselló et al. (2015) attributed the higher $\mathrm{Al}$ concentrations of $\mathrm{Al}$ in control plants to an efficient mechanism of $\mathrm{Al}$ exclusion in some genotypes, but not in all.

\section{Al Induces Transcription Factors Gene Expression in Roots of Rice Plants}

We analyzed the expression pattern of 57 NAC genes, of which 25 showed changes in gene expression after $24 \mathrm{~h}$ of exposure to $200 \mu \mathrm{M} \mathrm{Al}$, which represents $44 \%$ of all NAC genes tested. The fold change in the expression of those genes was evident in most cultivars tested (Table 1). A gene was considered Alregulated when the $\log _{2}$ of $2^{\Delta \Delta C t}$ was $\geq 2$ as an absolute value. Thus, in Cotaxtla plant roots 21 genes were found induced, 19 in Tres Ríos, 18 in Huimanguillo and 24 in Temporalero. We could also observe that three genes were exclusively induced in Temporalero: Os01g15640, Os10g21560, and Os04g40130; while Os06g51070 was only induced in Cotaxtla, Temporalero and Huimanguillo, but not in Tres Ríos. Similarly, the genes Os03g21060, Os09g33490, and OsNAC5 were induced in three of the four cultivars evaluated, but they were not found to be differentially expressed in Huimanguillo plants. Of the 25 genes found to be differentially expressed upon $\mathrm{Al}$ exposure, 14 (54\%) belong to the NAM (no apical meristem) subfamily (Table 1). 


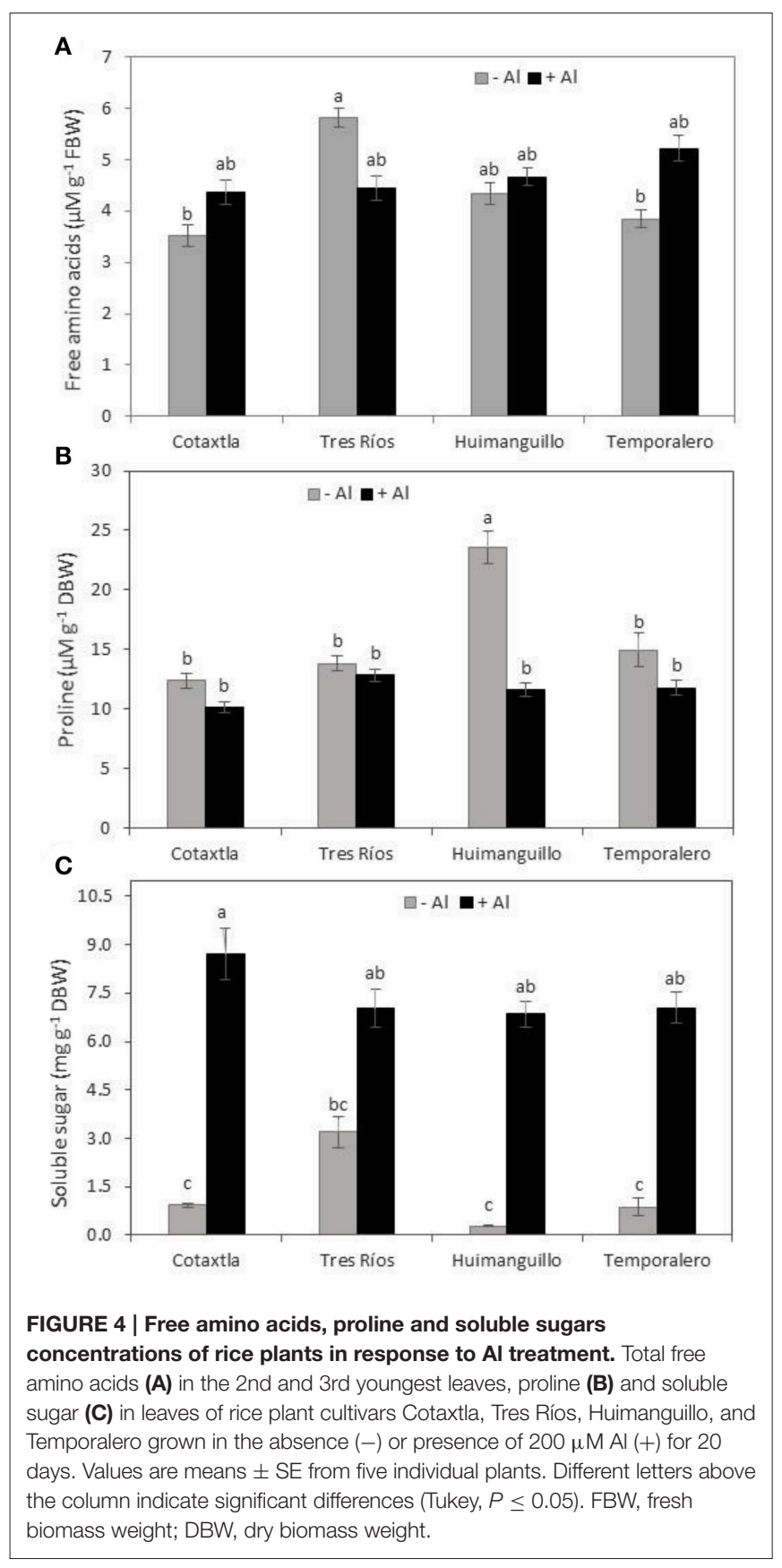

Furthermore, 20 genes were regulated both in Cotaxtla and Temporalero, 17 in Cotaxtla and Huimanguillo, 16 in Huimanguillo and Tres Ríos, and 18 in Tres Ríos and Temporalero. Of the 57 NAC genes evaluated, 15 genes were induced in all four cultivars tested, representing $60 \%$ of the total number of genes induced by $\mathrm{Al}$ in our study (Figure 7A). Moreover, we found that the gene OsDREB2A was only induced in Temporalero roots, whereas OsDREB2B1 and TRAB1 were upregulated in the four cultivars, though with a higher level in Cotaxtla and Temporalero. OsRAN2 was induced in Cotaxtla and Temporalero, but not in Tres Ríos or Huimanguillo (Figure 7B). In plants treated with $\mathrm{Al}$, our positive control ASR5 was induced in roots of Cotaxtla and Temporalero, while slightly repressed in Tres Ríos and Huimanguillo. Instead, the expression of STAR1 was induced in all four cultivars evaluated, but its expression was stronger in Cotaxtla, Huimanguillo and Temporalero.

\section{DISCUSSION}

\section{Aluminum Improves Growth and Stimulates Soluble Sugars Concentrations}

Plant species differ in their response to $\mathrm{Al}$ exposure, and rice has largely been found to be one of the most tolerant crops to toxic levels of $\mathrm{Al}$ (Famoso et al., 2010). In this study we confirmed that rice is indeed highly tolerant to $\mathrm{Al}$, and proved that our four cultivars increased plant height (Figure 1A), root length (Figure 1D), and biomass production (Figure 2) upon exposure to $200 \mu \mathrm{M}$ Al. In a previous study, Marín-Garza et al. (2010) evaluated growth parameters in the cultivars Tres Ríos, Huimanguillo and Temporalero in response to 0,200 , and 400 $\mu \mathrm{M} \mathrm{Al}$, though they found no significant differences regarding plant height. Subsequently, Gómez-Merino et al. (2014) reported that plant growth was significantly affected by $400 \mu \mathrm{M} \mathrm{Al}$, whereas with $200 \mu \mathrm{M} \mathrm{Al}$ root length was similar to the control (no $\mathrm{Al}$ added). Interestingly, Temporalero plants increased root length with $200 \mu \mathrm{M} \mathrm{Al}$, though this increase was not significant when compared to the control (Gómez-Merino et al., 2014). The differences found in our study in comparison to the results reported by Marín-Garza et al. (2010) and Gómez-Merino et al. (2014) may be attributed to the general management of the experiments: seed germination conditions (MS medium vs. filter paper in Petri dishes irrigated with distilled water); the nutrient solution employed for the hydroponic assay (Yoshida vs. Steiner); acclimation period in the nutrient solution before $\mathrm{Al}$ treatment application ( 2 weeks vs. 1 week); and age of plants before exposure to $\mathrm{Al}$ (24 days vs. 35 days). Similar results on the beneficial effect of $\mathrm{Al}$ in promoting growth in other plant species have been reported. For instance, tea plants (Camellia sinensis) exposed to $100 \mu \mathrm{M}$ Al developed better than those grown in Alfree media (Hajiboland et al., 2013a). In rice cultivar OM4900, Nhan and Hai (2013) found an increase of 35\% in shoot height in plants exposed to $400 \mu \mathrm{M}$ Al for 8 days. Moreover, Famoso et al. (2011) reported that exposure to $160 \mu \mathrm{M}$ Al triggered significant root elongation in rice, which is similar to our results. This may be due to the fact that $\mathrm{Al}$ diminishes $\mathrm{H}^{+}$toxicity when $\mathrm{pH}$ is low, as a consequence of an electrostatic shift in the cell membrane surface (Poschenrieder et al., 2015).

The stimulant effect of $\mathrm{Al}$ has also been reported in tea plants, where this element enhances biomass production both in shoots and roots, which is similar to our results (Figure 2). Even with a higher $\mathrm{Al}$ concentration (i.e., $300 \mu \mathrm{M} \mathrm{Al}$ ) than that tested here, Al-treated plants produced three-fold more biomass than control plants (Hajiboland et al., 2013a,b). A similar response was observed in tea plant suspension cells exposed to 0, 50, and $500 \mu \mathrm{M} \mathrm{Al}$ (Ghanati et al., 2005). In tea plants, Hajiboland et al. (2013b) also reported that the application of $300 \mu \mathrm{M} \mathrm{Al}$ boosts chlorophyll biosynthesis in young leaves, but not in old leaves. Likewise, our experiments 

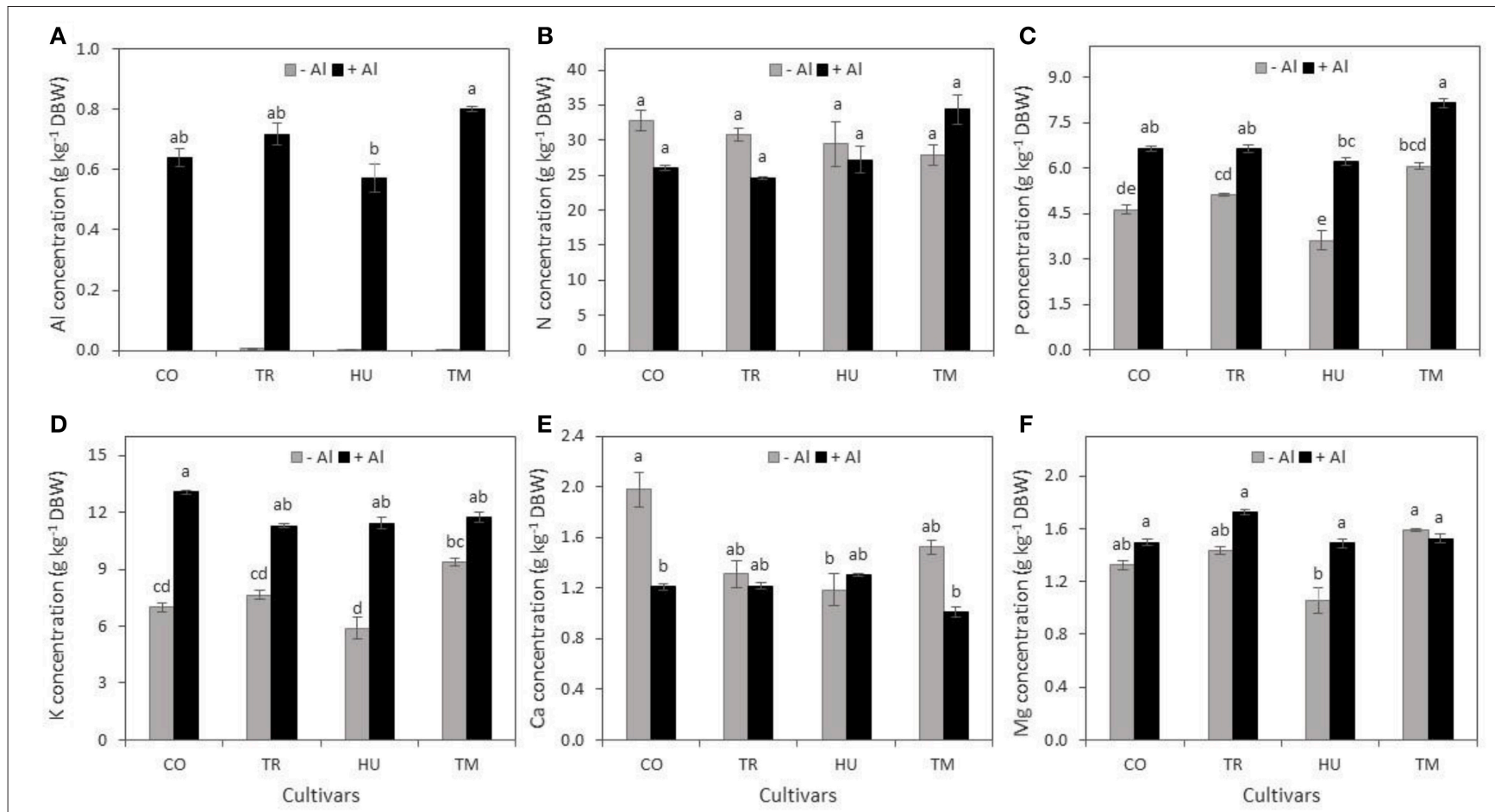

FIGURE 5 | Concentrations of aluminum and macronutrients in roots of rice plants in response to $\mathbf{A l}$ treatment. Concentration of $A(\mathbf{A}), \mathrm{N}(\mathrm{B}), \mathrm{P}(\mathbf{C}), \mathrm{K}(\mathrm{D})$, $\mathrm{Ca}(\mathbf{E})$, and $\mathrm{Mg}(\mathbf{F})$ in roots of rice plant cultivars Cotaxtla (CO), Tres Ríos (TR), Huimanguillo (HU), and Temporalero (TM) grown in the absence (-) or presence of 200 $\mu \mathrm{M} \mathrm{Al}(+)$ in the nutrient solution for 20 days. Values are means \pm SE from five individual plants. Different letters above the column indicate significant differences (Tukey, $P \leq 0.05)$. DBW, dry biomass weight.

also demonstrated that chlorophyll concentrations increased in young leaves of Al-treated Cotaxtla, Huimanguillo and Temporalero plants (Figures 3A-C, respectively). These results are also in full agreement with those reported by Nhan and Hai (2013) in rice plant cultivar OM4900, since both chlorophyll $a$ and $b$ were significantly higher in plants treated with 200,300, 400 , and $500 \mu \mathrm{M} \mathrm{AlCl}_{3}$, as compared with the control.

When exposed to stress conditions, plants tend to accumulate free amino acids, especially proline (Hayat et al., 2012). We found that $200 \mu \mathrm{M} \mathrm{Al}$ does not represent a stressful factor for the rice cultivars tested. Instead, we observed a stimulant effect on most variables measured, and would expect that both amino acids and proline were similar in Al-treated and control plants. We confirmed this hypothesis, since none of the cultivars assayed displayed significant differences regarding either amino acids (Figure 4A) or concerning proline (Figure 4B) concentrations in shoots. Similarly, in tea plants Al stimulated growth and biomass production, whereas amino acid concentrations were not affected (Hajiboland et al., 2013b). Since amino acids are precursors of proteins, no changes in the concentrations of amino acids in response to $\mathrm{Al}$ may indicate that there was no degradation of proteins in Altreated plants. Hajiboland et al. (2013b) also report a rise in proline concentration in leaves and roots of tea plants treated with $300 \mu \mathrm{M} \mathrm{Al}$, which was attributed to the important role of proline in removing free radicals in response to the acidic media triggering oxidative stress. Under our experimental conditions, we did not find different responses in proline concentrations in Al-treated and control plants, with the exception of Huimanguillo, which showed a reduction in proline concentration in response to $\mathrm{Al}$. This behavior could mean that this cultivar, in particular, possesses a less efficient antioxidant mechanism in comparison to the rest of the cultivars tested. Importantly, it has been reported that proline concentration is not always correlated with stress tolerance (Szabados and Savouré, 2010).

Likewise, total soluble sugars concentration may be closely correlated with tolerance to saline stress (Kong et al., 2011; Zhang et al., 2015). Herein we found that Al significantly increased soluble sugars in rice shoots. These results are different from those reported in tea plants, since young leaves and roots showed similar concentrations of such carbohydrates both in Al-treated and control plants, while in old leaves soluble sugars were reduced in response to $\mathrm{Al}$ exposure (Hajiboland et al., 2013b). Similar results to those reported herein have been observed in sunflower varieties Sirena and Sanbero, since exposure to 100 and $200 \mu \mathrm{M} \mathrm{Al}$ significantly increased soluble sugars concentration (Ziaei et al., 2014). Soluble sugars do not only function as metabolic resources and structural constituents of cells, but also act as signals regulating various processes associated with plant growth and development (Rosa et al., 2009). Hence, Al increases soluble sugars concentration in plants, which in turn may enhance growth and biomass production in rice under our experimental conditions. 

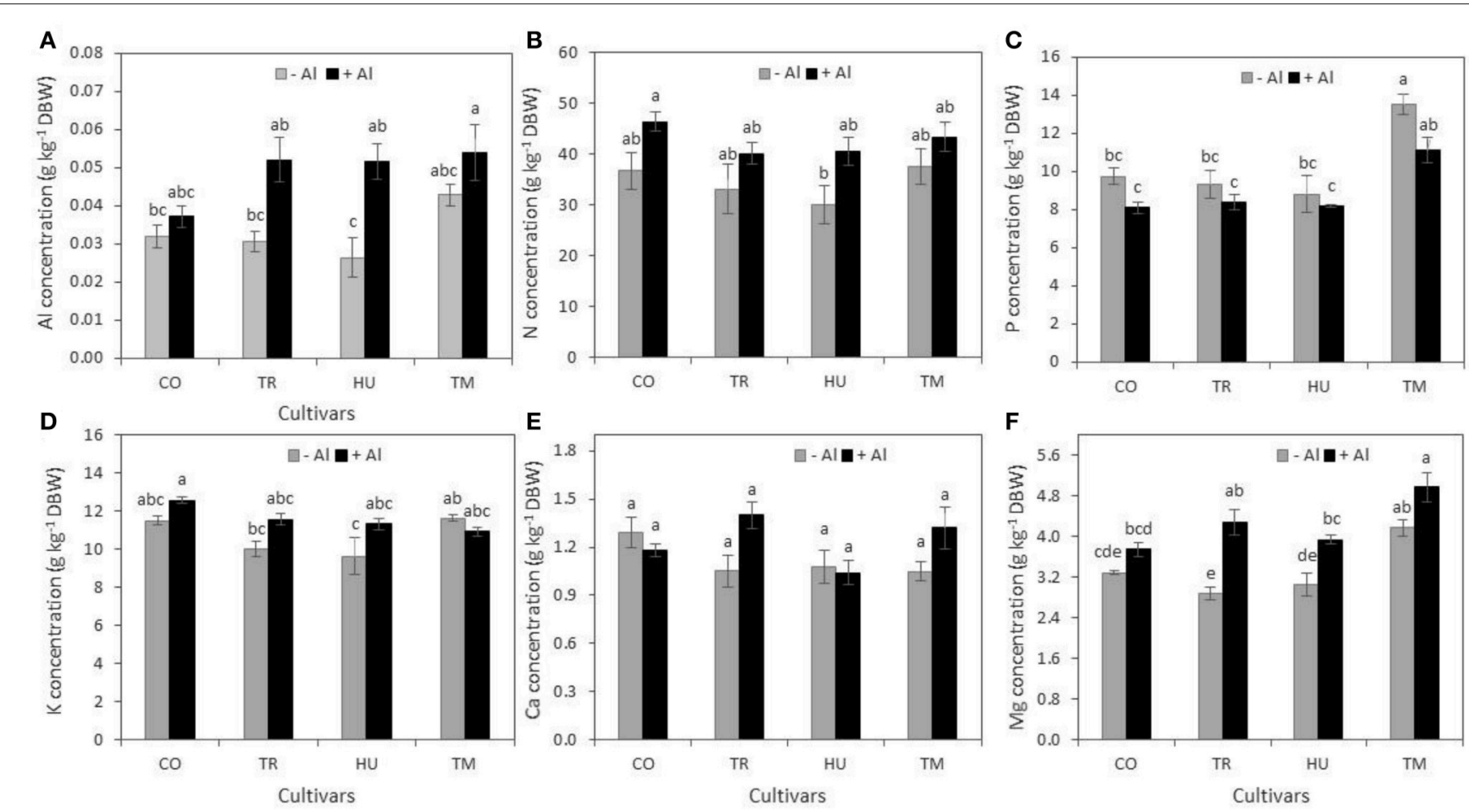

FIGURE 6 | Concentration of aluminum and macronutrients in shoots of rice plants under $\mathbf{A l}$ treatment. Concentration of $\mathrm{Al}$ (A), $\mathrm{N}$ (B), $\mathrm{P}$ (C), $\mathrm{K}$ (D), Ca (E), and $\mathrm{Mg}$ (F) in shoot of rice plant cultivars Cotaxtla (CO), Tres Ríos (TR), Huimanguillo (HU) and Temporalero (TM) grown in the absence (-) or presence of $200 \mu \mathrm{M}$ Al $(+)$ in the nutrient solution for 20 days. Values are means \pm SE from five individual plants. Different letters above the column indicate significant differences $($ Tukey, $P \leq$ 0.05). DBW = dry biomass weight.

\section{Aluminum Alters Macronutrients Concentration in Rice Plants}

All four rice cultivars evaluated displayed similar $\mathrm{Al}$ concentrations in roots $\left(0.68 \mathrm{~g} \mathrm{~kg}^{-1} \mathrm{DBW}\right.$ on average), with Huimanguillo showing the lowest and Temporalero the highest concentrations and differences between Al-treated and control plants were significant (Figure 5A). Nonetheless, in shoots, $\mathrm{Al}$ concentrations showed less differences between Al-treated and control plants (Figure 6A) and such values were indeed much lower than those found in roots (Figure 5A). In fact, $\mathrm{Al}$ concentrations in shoots ranged from $0.026 \mathrm{~g} \mathrm{~kg}^{-1} \mathrm{DBW}$ in Huimanguillo plants under control conditions (the lowest value in shoots), to $0.054 \mathrm{~g} \mathrm{~kg}^{-1} \mathrm{DBW}$ in Temporalero plants treated with $\mathrm{Al}$ (the highest value found in shoots). Interestingly, Cotaxtla and Temporalero displayed statistically similar values of $\mathrm{Al}$ concentrations in shoots in Al-treated and control plants, whereas Huimanguillo and Tres Ríos showed almost double the concentration of $\mathrm{Al}$ in $\mathrm{Al}$-treated plants, in comparison to the control. This response suggests that the first two cultivars (Cotaxtla and Temporalero) have developed more efficient mechanisms to restrict $\mathrm{Al}$ transport to the shoots, in comparison to the last two cultivars (Huimanguillo and Tres Ríos). Likewise, Roselló et al. (2015) reported that comparison of root and shoot $\mathrm{Al}$ concentrations between Nipponbare (Al-tolerant) and Modan (Al-sensitive) varieties demonstrated that the basis of the $\mathrm{Al}$ resistance strategy in Nipponbare is the avoidance of $\mathrm{Al}$ uptake into the roots and an efficient restriction of $\mathrm{Al}$ transport to the shoots. Modan was able to restrict Al translocation to the shoots only during the first $24 \mathrm{~h}$ of $\mathrm{Al}$ exposure. Then $\mathrm{Al}$ shoot concentrations increased reaching 2.5 times higher concentrations than the corresponding background values in the control plants. Contrastingly, Al concentrations were not enhanced in the shoots of Nipponbare during the $72 \mathrm{~h}$ exposure time. Poschenrieder et al. (2015) argue that contrasting responses among species and varieties can be explained by three different mechanisms: (1) the amelioration of $\mathrm{H}^{+}$toxicity by $\mathrm{Al}^{3+}$; (2) preventing $\mathrm{Al}$ to reach the target sites and damage; and (3) a putative (still unknown) mechanism that apparently implies a restructuring of the cell wall in the root tip after an initial highly sensitive response (activation of defense genes).

Aluminum exposure for long periods may lead to nutrient limitations, among which $\mathrm{Ca}, \mathrm{Mg}, \mathrm{N}$ (in the form of $\mathrm{NH}_{4}$ ), $\mathrm{P}$ and $\mathrm{K}$ are the most common deficiencies in acid soils with toxic levels of $\mathrm{Al}$ (Lenoble et al., 1996; Mariano and Keltjens, 2005). Interestingly, under our experimental conditions we did not find any deficiency in relation to the macronutrients $\mathrm{N}$, $\mathrm{P}, \mathrm{K}, \mathrm{Ca}$, and $\mathrm{Mg}$, neither in roots (Figure 5) nor in shoots (Figure 6). Similar results have been reported by Marín-Garza et al. (2010), since they did not find any deficiency of Ca, K, $\mathrm{Mg}$, and $\mathrm{P}$ in roots of cultivars Temporalero, Huimanguillo, and Tres Ríos grown either in 0 or $200 \mu \mathrm{M}$ Al containing solutions, though in Tres Ríos there was a reduction in $\mathrm{Ca}$ 
TABLE 1 | Expression levels of NAC genes in roots of rice plants in response to Al treatment.

\begin{tabular}{|c|c|c|c|c|c|}
\hline \multirow{2}{*}{$\begin{array}{l}\text { Locus Identifier } \\
\text { TIGR v5.0 }\end{array}$} & \multirow[t]{2}{*}{ Gene name } & \multicolumn{4}{|c|}{ Relative expression (Fold change) } \\
\hline & & Cotaxtla & Tres Ríos & Huimanguillo & Temporalero \\
\hline Os02g56600 & No apical meristem (NAM) protein, putative & $4.52 \pm 0.29 a$ & $4.40 \pm 0.37 a$ & $4.84 \pm 0.59 a$ & $4.39 \pm 0.33 a$ \\
\hline Os03g21060 & No apical meristem (NAM) protein, putative & $2.39 \pm 0.23 b$ & $2.50 \pm 0.24 b$ & $1.40 \pm 0.16 c$ & $5.17 \pm 0.09 a$ \\
\hline missing annotation: & No apical meristem (NAM) protein, putative & $4.66 \pm 0.47 a$ & $3.78 \pm 0.73 a b$ & $2.69 \pm 0.51 b$ & $5.04 \pm 0.31 a$ \\
\hline Os03g60080 & Putative NAC-domain protein & $8.59 \pm 0.49 a$ & $2.37 \pm 0.24 b$ & $3.12 \pm 0.29 b$ & $2.16 \pm 0.24 b$ \\
\hline Os10g42130 & putative NAM (no apical meristem) protein & $5.45 \pm 0.66 a$ & $4.18 \pm 0.40 a b$ & $3.38 \pm 0.23 b$ & $4.06 \pm 0.73 a b$ \\
\hline Os01g66490 & No apical meristem (NAM) protein, putative & $3.41 \pm 0.68 a b$ & $2.11 \pm 0.33 b$ & $3.13 \pm 0.2 \mathrm{ab}$ & $4.21 \pm 0.28 a$ \\
\hline Os01g15640 & No apical meristem (NAM) protein, putative & $1.63 \pm 0.28 b$ & $-0.32 \pm 0.26 c$ & $1.34 \pm 0.14 b$ & $3.26 \pm 0.50 a$ \\
\hline Os07g04560 & hypothetical protein & $6.11 \pm 0.22 \mathrm{a}$ & $-0.38 \pm 0.16 d$ & $1.64 \pm 0.16 c$ & $4.25 \pm 0.96 b$ \\
\hline Os09g32040 & Similar to NAM like protein 7 & $1.53 \pm 0.24 b$ & $-1.29 \pm 0.31 c$ & $3.05 \pm 0.54 b$ & $4.89 \pm 0.70 a$ \\
\hline Os12g43530 & No apical meristem (NAM) protein, putative & $7.62 \pm 0.65 a$ & $6.19 \pm 0.88 a b$ & $3.71 \pm 0.49 c$ & $4.6 \pm 0.23 b c$ \\
\hline Os06g51070 & NAM (no apical meristem)-like protein [imported] -Arabidopsis thaliana & $5.43 \pm 0.75 a$ & $1.51 \pm 0.30 b$ & $4.26 \pm 0.37 a$ & $2.60 \pm 0.10 b$ \\
\hline Os09g33490 & Similar to NAC domain protein NAC2 & $2.53 \pm 0.25 a b$ & $3.65 \pm 0.81 a$ & $1.89 \pm 0.44 b$ & $3.30 \pm 0.30 a b$ \\
\hline Os11g31330 & No apical meristem (NAM) protein, putative & $6.30 \pm 0.71 a$ & $6.17 \pm 0.38 a$ & $2.51 \pm 0.23 c$ & $4.38 \pm 0.38 b$ \\
\hline Os04g35660 & No apical meristem (NAM) protein, putative & $3.82 \pm 0.40 a b$ & $3.59 \pm 0.41 b$ & $3.21 \pm 0.15 b$ & $4.86 \pm 0.40 a$ \\
\hline missing annotation: & No apical meristem (NAM) protein, putative & $5.25 \pm 0.35 a$ & $4.26 \pm 0.17 \mathrm{ab}$ & $3.43 \pm 0.45 b$ & $1.68 \pm 0.15 c$ \\
\hline Os03g59730 & Putative No apical meristem (NAM) protein & $5.35 \pm 0.13 a$ & $4.43 \pm 0.54 a b$ & $3.82 \pm 0.01 b$ & $3.72 \pm 0.23 b$ \\
\hline Os07g13920 & No apical meristem (NAM) protein, putative & $4.87 \pm 0.34 b$ & $5.90 \pm 0.20 a$ & $2.63 \pm 0.23 d$ & $3.82 \pm 0.33 c$ \\
\hline Os10g21560 & putative transcription factor & $1.21 \pm 0.26 b$ & $-0.77 \pm 0.17 c$ & $1.48 \pm 0.12 b$ & $4.61 \pm 0.14 a$ \\
\hline Os04g40130 & Similar to probable salt-inducible protein [imported] - Arabidopsis thaliana & $1.56 \pm 0.12 b$ & $1.04 \pm 0.40 b$ & $1.72 \pm 0.22 b$ & $3.56 \pm 0.35 a$ \\
\hline Os08g10080 & Similar to NAC domain protein NAC1 & $5.10 \pm 0.23 a$ & $4.50 \pm 0.72 a$ & $3.91 \pm 0.56 a$ & $4.18 \pm 0.69 a$ \\
\hline Os12g29330 & Similar to NAC domain protein NAC2 & $4.70 \pm 0.66 a b$ & $4.74 \pm 0.43 a b$ & $3.08 \pm 0.48 b$ & $5.35 \pm 0.56 a$ \\
\hline Os04g38720 & OsNAC2 protein & $4.16 \pm 0.36 a$ & $4.78 \pm 0.54 a$ & $4.66 \pm 0.32 a$ & $4.20 \pm 0.53 a$ \\
\hline Os11g08210 & OsNAC5 protein [imported] - rice & $4.76 \pm 0.55 a b$ & $4.83 \pm 0.06 a$ & $3.15 \pm 0.53 b$ & $5.13 \pm 0.66 a$ \\
\hline Os11g08210 & OsNAC5 & $3.53 \pm 0.70 b$ & $2.95 \pm 0.18 b$ & $1.31 \pm 0.24 c$ & $5.31 \pm 0.52 a$ \\
\hline Os01g66120 & OsNAC6 & $4.96 \pm 0.52 a$ & $3.43 \pm 0.50 \mathrm{ab}$ & $4.77 \pm 0.40 a$ & $2.86 \pm 0.55 b$ \\
\hline
\end{tabular}

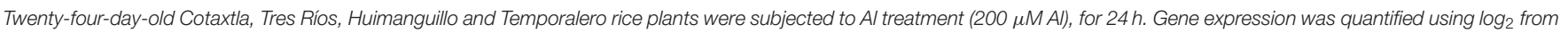

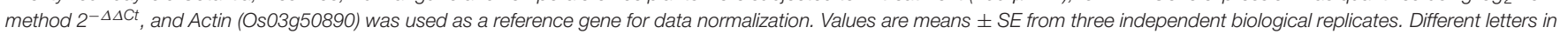
each row indicate significant differences (Fisher LSD test; $P \leq 0.05$ ).

concentration. One of the nutrients most affected by $\mathrm{Al}$ is $\mathrm{P}$, since it forms an Al-P complex of very low solubility, which reduces $\mathrm{P}$-availability in acid soils with high levels of toxic $\mathrm{Al}$ (Haynes and Mokolobate, 2001). Even in acid soils with high concentrations of $\mathrm{P}$, the availability of this nutrient is highly restricted (Fukuda et al., 2007). Surprisingly, herein we found a synergic effect of $\mathrm{Al}$ on $\mathrm{P}$, since $\mathrm{P}$ concentrations in roots of plants grown with $200 \mu \mathrm{M} \mathrm{Al}$ were higher than those found in control plants (Figure 5C); in shoots we were unable to find significant effects of $\mathrm{Al}$ on $\mathrm{P}$ concentrations (Figure 6C). A similar response was observed regarding $\mathrm{K}$ concentrations (Figures 5D, 6D). However, studies on the relationships between $\mathrm{Al}$ and $\mathrm{K}$ have produced controversial results. For instance, while Matsumoto and Yamaya (1986) and Nichol et al. (1993) observed that Al inhibits K uptake, Lindberg (1990) and Tanoi et al. (2005) reported an enhanced uptake of $\mathrm{K}$ driven by $\mathrm{Al}$. This response could be attributed to a reduction in the efflux of K, instead of increased absorption (Sasaki et al., 1995). On the other hand, it has been observed that toxic effects of $\mathrm{Al}$ cause Ca deficiencies (Rengel and Elliott, 1992). Furthermore, $\mathrm{Al}$ affects Ca cell homeostasis in plants (Bose et al., 2015). Nevertheless, it has also been reported that $\mathrm{Al}$ inhibits root hair growth without affecting $\mathrm{Ca}$ influx in Limnobium stoloniferum
(Jones et al., 1995). These findings, at least in part, coincide with our results, since with the exception of Cotaxtla we did not observe differences in $\mathrm{Ca}$ concentrations either in roots or shoot of plants grown in absence or presence $(200 \mu \mathrm{M} \mathrm{Al})$ of the metal (Figures 5E, 6E). Conversely, in Cotaxtla plants we observed a reduction of $\mathrm{Ca}$ concentration in roots in response to Al treatment (Figure 5E), though root growth was also enhanced (Figure 1D), as well as root biomass production (Figures 2C,D). It has also been reported that $\mathrm{Al}$ inhibits $\mathrm{Mg}$ uptake in Lolium multiflorum exposed to $26 \mu \mathrm{M}$ Al. This inhibition may be driven by a competitive interaction between $\mathrm{Al}$ and $\mathrm{Mg}$ for $\mathrm{Mg}$ transporters located in the plasma membrane (Rengel, 1990). On the contrary, our results demonstrate that Al-treated plants displayed a Mg concentration similar or even higher in Al-treated plants in comparison to control plants, both in roots (Figure 5F) and shoots (Figure 6F). Summarizing, Al treatment did not affect $\mathrm{N}$ and $\mathrm{Ca}$ concentrations in roots and shoots, or $\mathrm{P}$ and $\mathrm{K}$ in shoots; it had a synergic effect with $\mathrm{P}$ and $\mathrm{K}$ in roots, as well as with $\mathrm{Mg}$ in some cultivars (in roots of Huimanguillo and in shoots of Tres Ríos and Huimanguillo). Accordingly, Bose et al. (2015) argue that plants with the capacity of increasing P, Ca and $\mathrm{Mg}$ uptake show better growth under Al-stress conditions since they can absorb higher amounts of $\mathrm{H}^{+}$and at the same time 


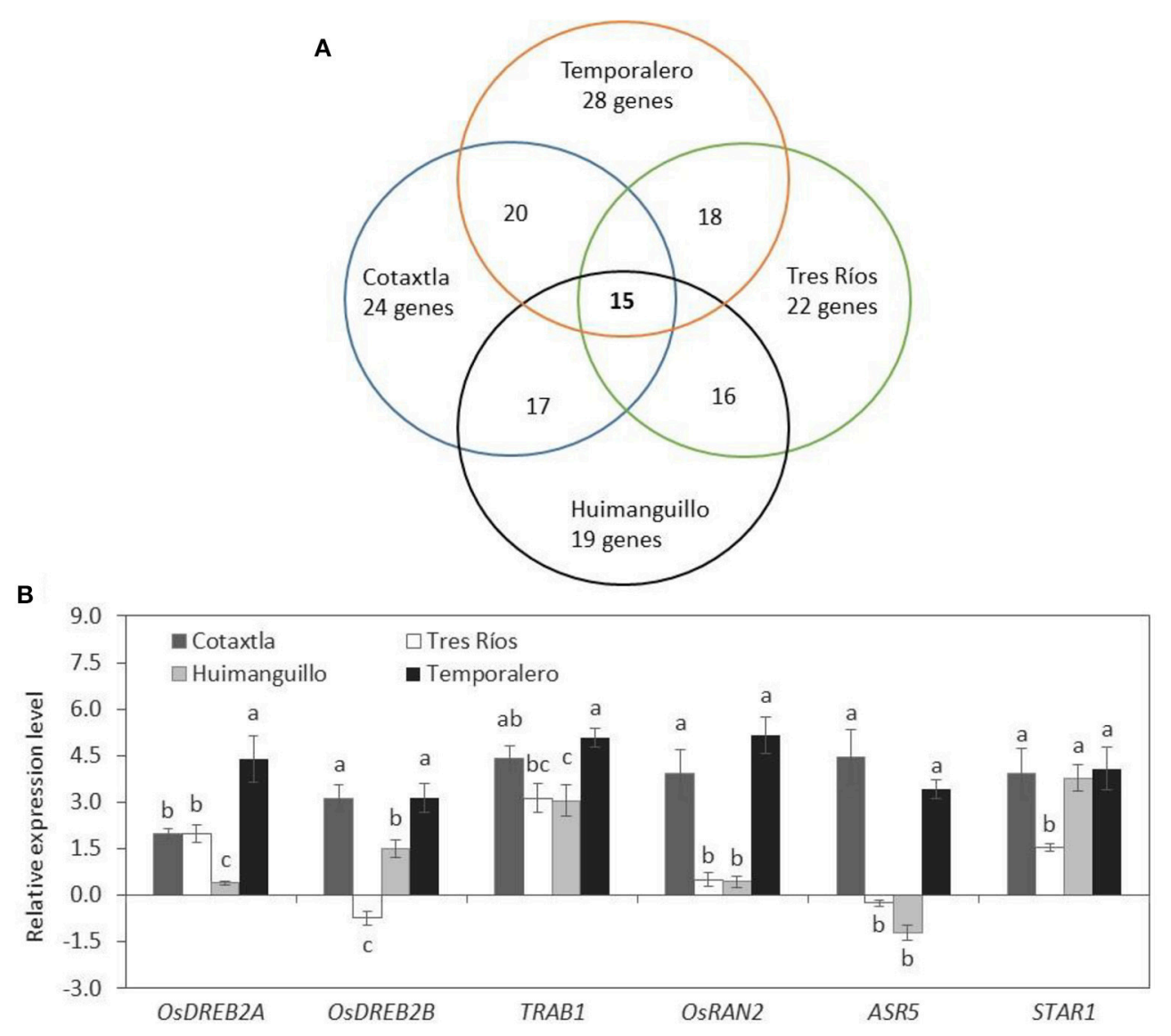

FIGURE 7 | Expression analysis of Aluminum-regulated genes in rice. Venn diagram depicts the number of Al-responsive NAC genes in roots of four rice cultivars (A). Relative expression level of other transcription factors and previously reported Al-responsive genes in Al-treated rice plants are shown (B). Total RNA was extracted from roots of rice plant cultivars Cotaxtla, Tres Ríos, Huimanguillo, and Temporalero grown in the absence (-) or presence of $200 \mu \mathrm{M}$ Al (+) in the nutrient solution for $24 \mathrm{~h}$. Relative gene expression was quantified using the $\log _{2}$ from method $2^{-\Delta \Delta \mathrm{Ct}}$, and Actin (Os03g50890) was used as a reference gene for data normalization. The values are mean \pm SE from three independent biological replicates. Different letters above the column indicate significant differences between cultivars evaluated (Fisher LSD test; $P \leq 0.05$ ).

prevent cytoplasmic acidification. Moreover, we confirm that $\mathrm{Al}$ as a beneficial element can increase availability of $\mathrm{P}$, which in turn is absorbed by roots in higher amounts.

\section{Expression Level of NAC Transcription Factor Genes Is Regulated by Al}

Transcription factors are proteins that bind to specific DNA sequences, thereby controlling the rate of transcription of genetic information from DNA to messenger RNA. They carry out their functions alone or with other proteins in a complex, by promoting (as an activator) or blocking (as a repressor) the recruitment of RNA polymerase to specific genes. Therefore, transcription factors play a pivotal role in modulating plant responses to environmental stimuli and stress agents, since they lead signaling cascades aimed at boosting expression of target genes, including those involved in $\mathrm{Al}$ metabolism and tolerance mechanisms (García-Morales et al., 2013; Garcia-Oliveira et al., 2015). The main transcription factors involved with Al tolerance in plants characterized so far belong to the $\mathrm{C} 2 \mathrm{H} 2$-type zincfinger family, which contain WRKY and Abscisic Acid, Stress and
Ripening (ASR) domains (Arenhart et al., 2014; Yokosho and Ma, 2015). Members of this family such as WRKY46 and ASR5 are also involved in tolerance mechanisms against other stress factors (Yokosho and Ma, 2015). Concerning NAC transcription factors, they are widespread in the plant kingdom (i.e., 117 in Arabidopsis and 151 in rice) (http://plntfdb.bio.uni-potsdam.de/v3.0/) and have been reported to be involved in vital processes in plant cells, including growth, development and responses to environmental stimuli and stressors. Indeed, a large amount of NAC genes have been implicated in both biotic and abiotic stress responses. For instance, the genes OsNAC5, OsNAC6, OsNAP, and SNAC1 in rice are induced by drought, salinity and cold stress (Nakashima et al., 2007; Takasaki et al., 2010; Saad et al., 2013; Chen et al., 2014). Herein we have demonstrated that two of those genes, OsNAC5 and OsNAC6, were also induced by $\mathrm{Al}$ treatment (Table 1). Importantly, an EST (Accession CA095885) similar to OsNAC5 was detected in an expression profiling analysis aimed at identifying Al-regulated genes in maize (Cançado et al., 2008), which further supports our findings. In our analysis, the expression OsNAC5 was found to be induced in response 
to $\mathrm{Al}$ in all four rice cultivars evaluated, though the highest level of induction was observed in Temporalero and the lowest in Huimanguillo. Our positive controls ASR5 and STAR1 also responded to $\mathrm{Al}$ under our experimental conditions.

Furthermore, we report that 14 NAC genes previously reported to be regulated by $\mathrm{NaCl}(100 \mathrm{mM})$ (García-Morales et al., 2014) are also regulated by Al. Moreover, the gene Os04g38720 was induced by $\mathrm{Al}$ in the four cultivars evaluated, and has been reported to be induced by cold too (Yun et al., 2010). The gene Os03g21060, which was previously reported to be induced by cold in Nipponbare (Yun et al., 2010), was also found to be induced by $\mathrm{Al}$ in the cultivars Cotaxtla, Tres Ríos and Temporalero. Just recently, Wang et al. (2016) reported that expression of the tomato NAC transcription factor SlNAC35 was induced by drought stress, salt stress, bacterial pathogens and signaling molecules, suggesting its involvement in plant responses to biotic and abiotic stimuli. Therefore, NAC transcription factors mediate in a wide range of biological processes, including growth, development and responses to environmental cues of both a biotic and abiotic nature. Herein we report for the first time that $N A C$ genes are induced by $\mathrm{Al}$ in rice, which open new avenues in the signal transduction pathways connecting this metal and the transcriptional machinery triggered by NAC proteins. Nevertheless, the molecular machinery underlying these pathways remains to be elucidated. In order to gain insight into these gaps, we are currently performing a comprehensive analysis of NAC genes promoters and their underlying mechanisms in transcriptional regulation, including epigenetic marks and chromatin-based regulation.

In addition to the NAC transcription factor genes tested, we also measured the expression pattern of other transcription factors belonging to the dehydration responsive element binding (DREB) family. OsDREB2A and OsDREB2B1 genes are responsive to low temperature, drought and salinity (Matsukura et al., 2010). The former showed Al-inducible gene expression in Temporalero plants, whereas the latter was induced in Cotaxtla and Tres Ríos plants in response to $\mathrm{Al}$ (Figure 7B). Interestingly, the overexpression of OsDREB2A in soybean (Glycine max) induced the expression of key genes involved in abiotic stress responses and drove significant increases in soluble sugars and proline concentrations, which in turn improved plant performance upon salt stress (Zhang et al., 2013). The gene TRAB1 is a member of the Basic Leucine Zipper (bZIP) proteins involved in abscisic acid signaling and stress responses (Yang et al., 2011). We found this gene to be induced by $\mathrm{Al}$, mainly in Temporalero and at a lower level in Huimanguillo (Figure 7B). Finally, OsRAN2 is a small GTPase, which when overexpressed in rice and Arabidopsis renders transgenic plants hypersensitive to salinity and osmotic stress (Zang et al., 2010) as well as cold stress (Xu and Cai, 2014). This gene was induced in Cotaxtla and Temporalero exposed to $\mathrm{Al}$, suggesting a possible role of this GTPase in Al metabolism and signaling. In order to further validate our results, we also analyzed the expression of two genes previously reported as Al-responsive: ASR5 and STAR1. The gene ASR5 (Abscisic acid, stress, and ripening) is expressed in chloroplasts, cytoplasm and nucleus, and rice plants with silenced
ASR genes are highly sensitive to Al (Arenhart et al., 2013, 2014, 2016). In our study, the expression of ASR5 in Al-treated plants was induced in Cotaxtla and Temporalero, but not in Tres Ríos and Huimanguillo (Figure 7B). Similarly, in the Al-sensitive cultivar Taim, ASR5 was not differentially regulated in plants exposed to $\mathrm{Al}$ (Freitas et al., 2006). Instead, Roselló et al. (2015) reported a slight induction of this gene in rice plants exposed to $500 \mu \mathrm{M} \mathrm{Al}$, but no differences were observed between subspecies (japonica cv. Nipponbare and indica cv. Modan). Importantly, ASR5 may act as a transcriptional regulator of multiple Alresponsive genes in rice, including STAR1 (Arenhart et al., 2014, 2016). STAR1 (sensitive to aluminum rhizotoxicity 1) encodes a nucleotide binding domain of a bacterial-type ATP binding cassette $(\mathrm{ABC})$ transporter, and is mainly expressed in roots of both Kishihikari wild-type and the mutant star1 rice plants (Huang et al., 2009). Under our experimental conditions, STAR1 was induced in three of the four rice cultivars evaluated (i.e., Cotaxtla, Huimanguillo and Temporalero) $24 \mathrm{~h}$ after exposure to $200 \mu \mathrm{M} \mathrm{Al}$ (Figure 7B). Roselló et al. (2015) found that STAR1 induction increased according to time period (from 0 to $48 \mathrm{~h}$ of exposure to $\mathrm{Al}$ ) in Nipponbare (japonica) plants, whereas in Modan (indica) the expression of this gene reached a maximum $24 \mathrm{~h}$ after $\mathrm{Al}$ exposure, and subsequently its expression decreased to values similar to those of the control (no Al added).

Transcription factors here evaluated have been shown to be differentially regulated by Al. Although deducing the biological role of their encoded proteins in Al metabolism and signaling remains a daunting challenge, herein we report for the first time that such genes are transcriptionally activated by a beneficial element inducing hormesis in rice. Interestingly, NAC genes have been identified in the genomes of important crop species such as grape, soybean, Chinese cabbage, maize, apple, potato, banana, tobacco, tomato and cassava (Shao et al., 2015). Nonetheless, further research is still needed to determine their particular physiological functions and to evaluate their potential as biotechnological tools to improve and expand the use of beneficial elements like Al. Importantly, beneficial elements have been postulated as key components for improving crop plant productivity and yield quality in light of global challenges such as climate change and increasing food demand. As a consequence of climate change, the impact of environmental stressors of both a biotic and abiotic nature hinders plant growth and agricultural productivity (Moyer, 2010). In fact, climate prediction models forecast that crop plants will have to cope with more stress factors occurring simultaneously in the future. Since NAC transcription factors have been shown to be commonly induced by multiple stresses, they represent promising candidates to breed broad-spectrum stress tolerant crops in order to meet increasing demand for food productivity under adverse agricultural conditions (Shao et al., 2015).

In conclusion, $\mathrm{Al}$ can provide outright stimulation to rice that might not occur with other crops. However, further research is required to find the right method of application (i.e., hydroponic solution, foliar spray, nanofertilizers, etc.), source, rate and phenological stage of $\mathrm{Al}$ application for different rice genotypes.

Because of environmental concerns and the narrow range between the stimulating and toxic concentrations of $\mathrm{Al}$, its 
practical use merits further research. However, studies of $\mathrm{Al}$ as a biostimulant have contributed to the increasing awareness of the relevance of this beneficial element for the efficient activation of plant growth. The connection between $\mathrm{Al}$ as a beneficial element in rice and the role of NAC transcription factors as key activators of $\mathrm{Al}$ signaling and integrating multiple stress responses will be essential for the development of broad-spectrum stress tolerant crop plants in the near future.

\section{AUTHOR CONTRIBUTIONS}

FG, SG, and LT developed and designed the experiments. FG and LT supervised the experiments. SG and MM carried out the physiological, biochemical and molecular analyses. LT was responsible for the nutrient analyses in plant tissues. SG, JH, and FG performed the data analyses. SG and FG wrote the

\section{REFERENCES}

Alcántar, G. G., and Sandoval, V. M. (1999). Manual de Análisis Químico de Tejido Vegetal. Chapingo: Sociedad Mexicana de la Ciencia del Suelo A.C.

Arenhart, R. A., Bai, Y., Valter, L. F., Bucker, L., Schunemann, M., dos Santos, F., et al. (2014). New insights into aluminum tolerance in rice: the ASR5 protein binds the STAR1 promoter and other Aluminum-responsive genes. Mol. Plant 7, 709-721. doi: 10.1093/mp/sst160

Arenhart, R. A., Lima, J. C., de Pedron, M., Carvalho, F. E. L., Silveira, J. A., Rosa, S. B., et al. (2013). Involvement of ASR genes in aluminium tolerance mechanisms in rice. Plant Cell Environ. 36, 52-67. doi: 10.1111/j.1365-3040.2012.02553.x

Arenhart, R. A., Schunemann, M., Bucker Neto, L., Margis, R., Wang, Z. Y., and Margis-Pinheiro, M. (2016). Rice ASR1 and ASR5 are complementary transcription factors regulating aluminium responsive genes. Plant Cell Environ. 39, 645-651. doi: 10.1111/pce.12655

Bailey, R. W. (1958). The reaction of pentoses with anthrone. Biochem. J. 68, 669-672. doi: 10.1042/bj0680669

Bates, L. S., Waldren, R. P., and Teare, I. D. (1973). Rapid determination of free proline for water-stress studies. Plant Soil 39, 205-207. doi: 10.1007/BF00018060

Bose, J., Babourina, O., Ma, Y., Zhou, M., Shabala, S., and Rengel, Z. (2015). "Specificity of ion uptake and homeostasis maintenance during acid and aluminium stresses," in Aluminum Stress Adaptation in Plant, Signaling and Communication in Plants, eds S. K. Panda and F. Baluska (Cham: Springer International Publishing), 229-251.

Bremner, J. M. (1996). “Nitrogen-total," in Methods of Soil Analysis Part 3-Chemical Methods. SSS Book Ser. 5.3, eds D. L. Sparks, A. L. Page, P. A. Helmke, and R. H. Loeppert (Madison, WI: Soil Science Society of America, American Society of Agronomy), 1085-1121.

Caldana, C., Scheible, W. R., Mueller-Roeber, B., and Ruzicic, S. (2007). A quantitative RT-PCR platform for high-throughput expression profiling of 2500 rice transcription factors. Plant Methods 3:7. doi: 10.1186/1746-4811-3-7

Cançado, G. M. A, Nogueira, F. T. S., Camargo, S. R., Drummond, R. D., Jorge, R. A., and Menossi, M. (2008). Gene expression profiling in maize roots under aluminum stress. Biol. Plant. 52, 475-485. doi: 10.1007/s10535-008-0093-5

Chen, X., Wang, Y., Lv, B., Li, J., Luo, L., Lu, S., et al. (2014). The NAC family transcription factor OsNAP confers abiotic stress response through the ABA pathway. Plant Cell Physiol. 55, 604-619. doi: 10.1093/pcp/pct204

Ding, Z. J., Yan, J. Y., Xu, X. Y., Li, G. X., and Zheng, S. J. (2013). WRKY46 functions as a transcriptional repressor of ALMT1, regulating aluminum-induced malate secretion in Arabidopsis. Plant J. 76, 825-835. doi: $10.1111 /$ tpj.12337

Du, B., Nian, H., Zhang, Z., and Yang, C. (2010). Effects of aluminum on superoxide dismutase and peroxidase activities, and lipid peroxidation in the manuscript. FG and LT revised the manuscript. MM and SG contributed equally to this work.

\section{ACKNOWLEDGMENTS}

The authors are grateful to Mexico's National Council for Science and Technology (CONACYT) for the M.Sc. scholarship given to MM, and the Plant Nutrition and Seed Biotechnology Laboratories at the Montecillo Campus of the Colegio de Postgraduados for providing infrastructure and financial support.

\section{SUPPLEMENTARY MATERIAL}

The Supplementary Material for this article can be found online at: http://journal.frontiersin.org/article/10.3389/fpls.2017. 00073/full\#supplementary-material roots and calluses of soybeans differing in aluminum tolerance. Acta Physiol. Plant. 32, 883-890. doi: 10.1007/s11738-010-0476-z

Famoso, A. N., Clark, R. T., Shaff, J. E., Craft, E., McCouch, S. R., and Kochian, L. V. (2010). Development of a novel aluminum tolerance phenotyping platform used for comparisons of cereal aluminum tolerance and investigations into rice aluminum tolerance mechanisms. Plant Physiol. 153, 1678-1691. doi: $10.1104 / p p .110 .156794$

Famoso, A. N., Zhao, K., Clark, R. T., Tung, C.-W., Wright, M. H., Bustamante, C., et al. (2011). Genetic architecture of aluminum tolerance in rice (Oryza sativa) determined through genome-wide association analysis and QTL mapping. PLoS Genet. 7:e1002221. doi: 10.1371/journal.pgen.1002221

Freitas, F. A., Kopp, M. M., de Sousa, R. O., Zimmer, P. D., de Carvalho, F. I. F., and de Oliveira, A. C. (2006). Nutrient absorption in aluminum stressed rice plants under hydroponic culture. Ciencia Rural 36, 72-79. doi: 10.1590/S0103-84782006000100011

Fukuda, T., Saito A., Wasaki, J., Shinano, T., and Osaki, M. (2007). Metabolic alterations proposed by proteome in rice roots grown under low $\mathrm{P}$ and high Al concentration under low pH. Plant Sci. 172, 1157-1165. doi: 10.1016/j.plantsci.2007.02.020

García-Morales, S., Gómez-Merino, F. C., and Trejo-Téllez, L. I. (2014). NAC transcription factor expression, amino acid concentration and growth of elite rice cultivars upon salt stress. Acta Physiol. Plant. 36, 1927-1936. doi: 10.1007/s11738-014-1569-x

García-Morales, S., Gómez-Merino, F. C., Trejo-Téllez, L. I., and Herrera-Cabrera, E. B. (2013). Transcription factors involved in molecular responses of plants to osmotic stress. Rev. Fitotec. Mex. 36, 105-115. Available online at: http://www. scielo.org.mx/pdf/rfm/v36n2/v36n2a3.pdf

Garcia-Oliveira, A. L., Poschenrieder, C., Barceló, J., and Martins-Lopes, P. (2015). "Breeding for $\mathrm{Al}$ tolerance by unravelling genetic diversity in bread wheat," in Aluminum Stress Adaptation in Plants, Signaling and Communication in Plants, eds S. K. Panda and F. Baluska (Cham: Springer International Publishing), $125-153$.

Geiger, M., Walch-Liu, P., Engels, C., Harnecker, J., Schulze, E. D., Ludewig, F., et al. (1998). Enhanced carbon dioxide leads to a modified diurnal rhythm of nitrate reductase activity in older plants, and a large stimulation of nitrate reductase activity and higher levels of amino acids in young tobacco plants. Plant Cell Environ. 21, 253-268. doi: 10.1046/j.1365-3040.1998.00277.x

Ghanati, F., Morita, A., and Yokota, H. (2005). Effects of aluminum on the growth of tea plant and activation of antioxidant system. Plant Soil 276, 133-141. doi: 10.1007/s11104-005-3697-y

Gómez-Merino, F. C., Trejo-Téllez, L. I., and Marín-Garza, T. (2014). Concentration and root growth in rice varieties exposed to aluminum. Rev. Fitotec. Mex. 37, 243-248. Available online at: http://www.scielo.org.mx/pdf/ $\mathrm{rfm} / \mathrm{v} 37 \mathrm{n} 3 / \mathrm{v} 37 \mathrm{n} 3 \mathrm{a} 10 . \mathrm{pdf}$ 
Hajiboland, R., Barceló, J., Poschenrieder, C., and Tolrà, R. (2013a). Amelioration of iron toxicity: a mechanism for aluminum-induced growth stimulation in tea plants. J. Inorg. Biochem. 128, 183-187. doi: 10.1016/j.jinorgbio.2013.07.007

Hajiboland, R., Rad, S. B., Barceló, J., and Poschenrieder, C. (2013b). Mechanisms of aluminum-induced growth stimulation in tea (Camellia sinensis). J. Plant Nutr. Soil Sci. 176, 616-625. doi: 10.1002/jpln.201200311

Hayat, S., Hayat, Q., Alyemeni, M. N., Wani, A. S., Pichtel, J., and Ahmad, A. (2012). Role of proline under changing environments: a review. Plant Signal. Behav. 7, 1456-1466. doi: 10.4161/psb.21949

Haynes, R., and Mokolobate, M. (2001). Amelioration of Al toxicity and P deficiency in acid soils by additions of organic residues: a critical review of the phenomenon and the mechanisms involved. Nutr. Cycl. Agroecosyst. 59, 47-63. doi: 10.1023/A:1009823600950

Hong, Y., Zhang, H., Huang, L., Li, D., and Song, F. (2016). Overexpression of a stress-responsive NAC transcription factor gene ONAC022 improves drought and salt tolerance in rice. Front. Plant Sci. 7:4. doi: 10.3389/fpls.2016.00004

Huang, C.F., Yamaji, N., Mitani, N., Yano, M., Nagamura, Y., and Ma, J. F. (2009). A bacterial-type $\mathrm{ABC}$ transporter is involved in aluminum tolerance in rice. Plant Cell 21, 655-667. doi: 10.1105/tpc.108.064543

Jansen, S., Broadley, M. R., Robbrecht, E., and Smets, E. (2002). Aluminum hyperaccumulation in angiosperms: a review of its phylogenetic significance. Bot. Rev. 68, 235-269. doi: 10.1663/0006-8101(2002)068[0235:AHIAAR]2.0. $\mathrm{CO} ; 2$

Jeong, J. S., Kim, Y. S., Baek, K. H., Jung, H., Ha, S. H., Choi, Y. D., et al. (2010). Root-specific expression of OsNAC10 improves drought tolerance and grain yield in rice under field drought conditions. Plant Physiol. 153, 185-197. doi: 10.1104/pp.110.154773

Jones, D. L., Shaff, J. E., and Kochian, L. V. (1995). Role of calcium and other ions in directing root hair tip growth in Limnobium stoloniferum. Planta 197, 672-680. doi: 10.1007/BF00191575

Joshi, R., Kumar, P. (2012). Lysigenous aerenchyma formation involves nonapoptotic programmed cell death in rice (Oryza sativa L.) roots. Physiol. Mol. Biol. Plants 18, 1-9. doi: 10.1007/s12298-011-0093-3

Kim, J. Y., Kim, W. Y., Kwak, K. J., Oh, S. H., Han, Y. S., and Kang, H. (2010). Glycine-rich RNA-binding proteins are functionally conserved in Arabidopsis thaliana and Oryza sativa during cold adaptation process. J. Exp. Bot. 61, 2317-2325. doi: 10.1093/jxb/erq058

Kobayashi, Y., Ohyama, Y., Kobayashi, Y., Ito, H., Iuchi, S., Fujita, M., et al. (2014). STOP2 activates transcription of several genes for Al- and low pHtolerance that are regulated by STOP1 in Arabidopsis. Mol. Plant 7, 311-322. doi: $10.1093 / \mathrm{mp} / \mathrm{sst} 116$

Kochian, L. V., Piñeros, M. A., and Hoekenga, O. A. (2005). The physiology, genetics and molecular biology of plant aluminum resistance and toxicity. Plant Soil 274, 175-195. doi: 10.1007/s11104-004-1158-7

Kong, X., Pan, J., Zhang, M., Xing, X., Zhou, Y., Liu, Y., et al. (2011). ZmMKK4, a novel group $\mathrm{C}$ mitogen-activated protein kinase kinase in maize (Zea mays), confers salt and cold tolerance in transgenic Arabidopsis. Plant Cell Environ. 34, 1291-1303. doi: 10.1111/j.1365-3040.2011.02329.x

Le, D. T., Nishiyama, R., Watanabe, Y., Mochida, K., Yamaguchi-Shinozaki, K., Shinozaki, K., et al. (2011). Genome-wide survey and expression analysis of the plant-specific NAC transcription factor family in soybean during development and dehydration stress. DNA Res. 18, 263-276. doi: 10.1093/dnares/dsr015

Lenoble, M. E., Blevins, D. G., Sharp, R. E., and Cumbie, B. G. (1996). Prevention of aluminium toxicity with supplemental boron. I. Maintenance of root elongation and cellular structure. Plant Cell Environ. 19, 1132-1142. doi: 10.1111/j.1365-3040.1996.tb00428.x

Lindberg, S. (1990). Aluminium interactions with $\mathrm{K}^{+}\left({ }^{86} \mathrm{Rb}^{+}\right)$and ${ }^{45} \mathrm{Ca}^{2+}$ fluxes in three cultivars of sugar beet (Beta vulgaris). Physiol. Plant. 79, 275-282. doi: 10.1111/j.1399-3054.1990.tb06742.x

Liu, J., Magalhaes, J. V., Shaff, J., and Kochian, L. V. (2009). Aluminum-activated citrate and malate transporters from the MATE and ALMT families function independently to confer Arabidopsis aluminum tolerance. Plant J. 57, 389-399. doi: 10.1111/j.1365-313X.2008.03696.x

Lu, G., Gao, C., Zheng, X., and Han, B. (2009). Identification of OsbZIP72 as a positive regulator of ABA response and drought tolerance in rice. Planta 229, 605-615. doi: 10.1007/s00425-008-0857-3

Ma, J. F., and Ryan, P.R. (2010). Understanding how plants cope with acid soils. Funct. Plant Biol. 37, 3-6. doi: 10.1071/FPv37n4_FO
Mariano, E. D., and Keltjens, W. G. (2005). Long-term effects of aluminum exposure on nutrient uptake by maize genotypes differing in aluminum resistance. J. Plant Nutr. 28, 323-333. doi: 10.1081/PLN-200047625

Marín-Garza, T., Gómez-Merino, F. C., Trejo-Téllez, L. I., Muñoz-Orozco, A., Tavitas-Fuentes, L., Hernández-Aragón, L., et al. (2010). Physiological and nutrimental responses of rice varieties to aluminium concentration. Rev. Fitotec. Mex. 33, 37-44. Available online at: http://www.scielo.org.mx/pdf/rfm/ v33n1/v33n1a7.pdf

Matsukura, S., Mizoi, J., Yoshida, T., Todaka, D., Ito, Y., Maruyama, K., et al. (2010). Comprehensive analysis of rice DREB2-type genes that encode transcription factors involved in the expression of abiotic stress-responsive genes. Mol. Genet. Genomics 283, 185-196. doi: 10.1007/s00438-0090506-y

Matsumoto, H., and Motada, H. (2012). Aluminum toxicity recovery processes in root apices. Possible association with oxidative stress. Plant Sci. 185-186, 1-8. doi: 10.1016/j.plantsci.2011.07.019

Matsumoto, H., Riechers, D. E., Lygin, A. V., Baluska, F., and Sivagura, M. (2015). "Aluminum signaling and potential links with safener-induced detoxification in plants," in Aluminum Stress Adaptation in Plant, Signaling and Communication in Plants, eds S. K. Panda and F. Baluska (Cham: Springer International Publishing), 1-35. doi: 10.1007/978-3-319-19968-9_1

Matsumoto, H., and Yamaya, T. (1986). Inhibition of potassium uptake and regulation of membrane-associated $\mathrm{Mg}^{2+}$-ATPase activity of pea roots by aluminium. Soil Sci. Plant Nutr. 32, 179-188. doi: 10.1080/00380768.1986.10557495

Moore, S., and Stein, W. H. (1954). A modified ninhydrin reagent for the photometric determination of amino acids and related compounds. J. Biol. Chem. 211, 907-913.

Moyer, M. (2010). How much is left? Sci. Am. 303, 74-81. doi: 10.1038/scientificamerican0910-74

Murashige, T., and Skoog, F. (1962). A revised medium for rapid growth and bio assays with tobacco tissue cultures. Physiol. Plant. 15, 473-497. doi: 10.1111/j.1399-3054.1962.tb08052.x

Nakashima, K., Tran, L. S., Van Nguyen, D., Fujita, M., Maruyama, K., Todaka, D., et al. (2007). Functional analysis of a NAC-type transcription factor OsNAC6 involved in abiotic and biotic stress-responsive gene expression in rice. Plant $\mathrm{J}$. 51, 617-630. doi: 10.1111/j.1365-313X.2007.03168.x

Nakashima, K., Yamaguchi-Shinozaki, K., and Shinozaki, K. (2014). The transcriptional regulatory network in the drought response and its crosstalk in abiotic stress responses including drought, cold, and heat. Front. Plant Sci. 5:170. doi: $10.3389 /$ fpls.2014.00170

Nhan, P. P., and Hai, N. T. (2013). Amelioration of aluminum toxicity on OM4900 rice seedlings by sodium silicate. Afr. J. Plant Sci. 7, 208-2012. doi: $10.5897 /$ AJPS11.306

Nichol, B. E., Oliveira, L. A., Glass, A. D. M., and Siddiqi, M. Y. (1993). The effects of aluminum on the influx of calcium, potassium, ammonium, nitrate, and phosphate in an aluminum-sensitive cultivar of barley (Hordeum vulgare L.). Plant Physiol. 101, 1263-1266. doi: 10.1104/pp.101.4.1263

Nuruzzaman, M., Sharoni, A. M., and Kikuchi, S. (2013). Roles of NAC transcription factors in the regulation of biotic and abiotic stresses responses in plants. Front. Microbiol. 4:248. doi: 10.3389/fmicb.2013.00248

Osaki, M. T., Watanabe, T., and Tadano, T. (1997). Beneficial effect of aluminum on growth of plants adapted to low pH soils. Soil Sci. Plant Nutr. 43, 551-563. doi: 10.1080/00380768.1997.10414782

Pilon-Smits, E. A. H., Quinn, C. F., Tapken, W., Malagoli, M., and Schiavon, M. (2009). Physiological functions of beneficial elements. Curr. Opin. Plant Biol. 12, 267-274. doi: 10.1016/j.pbi.2009.04.009

Poschenrieder, C., Tolrà, R., Hajiboland, R., Arroyave, C., and Barceló, J. (2015). "Mechanisms of hyper-resistance and hyper-tolerance to aluminum in plants," in Aluminum Stress Adaptation in Plants, Signaling and Communication in Plants, eds S. K. Panda and F. Baluska (Cham: Springer International Publishing), 81-98.

Potter, D. A., Powell, A. J., Spicer, P. G., and Williams, D. W. (1996). Cultural practices affect root- feeding white grubs (Coleoptera: Scarabaeidae) in turfgrass. J. Econ. Entomol. 89, 156-164. doi: 10.1093/jee/89.1.156

Rengel, Z. (1990). Competitive $\mathrm{Al}^{3+}$ inhibition of net $\mathrm{Mg}^{2+}$ uptake by intact Lolium multiflorum roots: II. Plant age effects. Plant Physiol. 93, 1261-1267. doi: $10.1104 /$ pp.93.3.1261 
Rengel, Z., and Elliott, D. C. (1992). Mechanism of aluminum inhibition of net ${ }^{45} \mathrm{Ca}^{2+}$ uptake by Amaranthus protoplasts. Plant Physiol. 98, 632-638. doi: $10.1104 /$ pp.98.2.632

Rosa, M., Prado, C., Podazza, G., Interdonato, R., González, J. A., Hilal, M., et al. (2009). Soluble sugars-Metabolism, sensing and abiotic stress. A complex network in the life of plants. Plant Signal. Behav. 4, 388-393. doi: $10.4161 /$ psb.4.5.8294

Roselló, M., Poschenrieder, C., Gunsé, B., Barceló, J., and Llugany, M. (2015). Differential activation of genes related to aluminium tolerance in two contrasting rice cultivars. J. Inorg. Biochem. 152, 160-166. doi: 10.1016/j.jinorgbio.2015.08.021

Saad, A. S., Li, X., Li, H. P., Huang, T., Gao, C. S., Guo, M. W., et al. (2013). A rice stress- responsive NAC gene enhances tolerance of transgenic wheat to drought and salt stresses. Plant Sci. 203-204, 33-40. doi: 10.1016/j.plantsci.2012.12.016

Sade, H., Meriga, B., Surapu, V., Gadi, J., Sunita, M. S., Suravajhala, P., et al. (2016). Toxicity and tolerance of aluminum in plants: tailoring plants to suit to acid soils. Biometals 29, 187-210. doi: 10.1007/s10534-016-9910-Z

Sasaki, M., Kasai, M., Yamamoto, Y., and Matsumoto, H. (1995). Involvement of plasma membrane potential in the tolerance mechanism of plant roots to aluminium toxicity. Plant Soil 171, 119-124. doi: 10.1007/BF00009573

SAS Institute (2004). Statistical Analysis System, Version 9.1. User's Guide. Cary, NC: SAS Institute.

Sawaki, Y., Iuchi, S., Kobayashi, Y., Kobayashi, Y., Ikka, T., Sakurai, N., et al. (2009). STOP1 regulates multiple genes that protect Arabidopsis from proton and aluminum toxicities. Plant Physiol. 150, 281-294. doi: 10.1104/pp.108.134700

Schmittgen, T. D., and Livak, K. J. (2008). Analyzing real-time PCR data by the comparative $\mathrm{C}_{\mathrm{T}}$ method. Nat. Protoc. 3, 1101-1108. doi: 10.1038/nprot.2008.73

Shao, H., Wang, H., and Tang, X. (2015). NAC transcription factors in plant multiple abiotic stress responses: progress and prospects. Front. Plant Sci. 6:902. doi: 10.3389/fpls.2015.00902

Sperotto, R. A., Ricachenevsky, F. K., Duarte, G. L., Boff, T., Lopes, K. L., Sperb, E. R., et al. (2009). Identification of up-regulated genes in flag leaves during rice grain filling and characterization of OsNAC5, a new ABA-dependent transcription factor. Planta 230, 985-1002. doi: 10.1007/s00425-009-1000-9

Szabados, L., and Savouré A. (2010). Proline: a multifunctional amino acid. Trends Plant Sci. 15, 89-97. doi: 10.1016/j.tplants.2009.11.009

Takasaki, H., Maruyama, K., Kidokoro, S., Ito, Y., Fujita, Y., Shinozaki, K., et al. (2010). The abiotic stress-responsive NAC-type transcription factor OsNAC5 regulates stress-inducible genes and stress tolerance in rice. Mol. Genet. Genomics 284, 173-183. doi: 10.1007/s00438-010-0557-0

Tanoi, K., Hojo, J., Suzuki, K., Hayashi, Y., Nishiyama, H., and Nakanishi, T. M. (2005). Analysis of potassium uptake by rice roots treated with aluminum using a positron emitting nuclide, ${ }^{38} \mathrm{~K}$. Soil Sci. Plant Nutr. 51, 715-717. doi: 10.1111/j.1747-0765.2005.tb00098.x

Vandesompele, J., De Preter, K., Pattyn, F., Poppe, B., Van Roy, N., De Paepe, A., et al. (2002). Accurate normalization of real-time quantitative RT-PCR data by geometric averaging of multiple internal control genes. Genome Biol. 3:Research0034. doi: 10.1186/gb-2002-3-7-research0034

Wang, G., Zhang, S., Ma, X., Wang, Y., Kong, F., and Meng, Q. (2016). A stress-associated NAC transcription factor (SINAC35) from tomato plays a positive role in biotic and abiotic stresses. Physiol. Plant. 158, 45-64. doi: $10.1111 /$ ppl.12444

Wang, L., Fan, X. W., Pan, J. L., Huang, Z. B., and Li, Y. Z. (2015). Physiological characterization of maize tolerance to low dose of aluminum, highlighted by promoted leaf growth. Planta 242, 1391-1403. doi: 10.1007/s00425-015-2376-3

Watanabe, T., Jansen, S., and Osaki, M. (2005). The beneficial effect of aluminium and the role of citrate in $\mathrm{Al}$ accumulation in Melastoma malabathricum. New Phytol. 165, 773-780. doi: 10.1111/j.1469-8137.2004.01261.x
$\mathrm{Xu}, \mathrm{P}$, and Cai, W. (2014). RAN1 is involved in plant cold resistance and development in rice (Oryza sativa). J. Exp. Bot. 65, 3277-3287. doi: $10.1093 /$ jxb/eru178

Yamaji, N., Huang, C. F., Nagao, S., Yano, M., Sato, Y., Nagamura, Y., et al. (2009). A zinc finger transcription factor ART1 regulates multiple genes implicated in aluminum tolerance in rice. Plant Cell 21, 3339-3349. doi: 10.1105/tpc.109.070771

Yamauchi, M., Aragones, D. V., Casayuran, P. R., Cruz, P. C. S., Asis, C. A., and Cruz, R.T. (2000). Seedling establishment and grain yield of tropical rice sown in puddled soil. Agron. J. 92, 275-282. doi: 10.2134/agronj2000.922275x

Yang, X., Römheld, V., and Marschner, H. (1994). Effect of bicarbonate on root growth and accumulation of organic acids in $\mathrm{Zn}$-inefficient and $\mathrm{Zn}$ efficient rice cultivars (Oryza sativa L.). Plant Soil 164, 1-7. doi: 10.1007/BF000 10104

Yang, X., Yang, Y. N., Xue, L. J., Zou, M. J., Liu, J. J., Chen, F., et al. (2011). Rice ABI5-Like1 regulates abscisic acid and auxin responses by affecting the expression of ABRE-containing genes. Plant Physiol. 156, 1397-1409. doi: $10.1104 /$ pp.111.173427

Yokosho, K., and Ma, J. F. (2015). "Transcriptional regulation of Al tolerance in plants," in Aluminum Stress Adaptation in Plant, Signaling and Communication in Plants, eds S. K. Panda and F. Baluska (Cham: Springer International Publishing), 37-46.

Yun, K. Y., Park, M. R., Mohanty, B., Herath, V., Xu, F., Mauleon, R., et al. (2010). Transcriptional regulatory network triggered by oxidative signals configures the early response mechanisms of japonica rice to chilling stress. BMC Plant Biol. 10:e16. doi: 10.1186/1471-2229-10-16

Zang, A., Xu, X., Neill, S., and Cai, W. (2010). Overexpression of OsRAN2 in rice and Arabidopsis renders transgenic plants hypersensitive to salinity and osmotic stress. J. Exp. Bot. 61, 777-789. doi: 10.1093/jxb/ erp341

Zhang, M., Kong, X., Xu, X., Li, C., Tian, H., and Ding, Z. (2015). Comparative transcriptome profiling of the maize primary, crown and seminal root in response to salinity stress. PLoS ONE 10:e0121222. doi: 10.1371/journal.pone.0121222

Zhang, X., Humphries, A., and Auricht, G. (2007). Genetic variability and inheritance of aluminium tolerance as indicated by long root regrowth in lucerne (Medicago sativa L.). Euphytica 157, 177-184. doi: 10.1007/s10681-007-9409-3

Zhang, X. X., Tang, Y. J., Ma, Q. B., Yang, C. Y., Mu, Y. H., Suo, H. C., et al. (2013). OsDREB2A, a rice transcription factor, significantly affects salt tolerance in transgenic soybean. PLOS ONE 8:e 83011. doi: 10.1371/journal.pone.0083011

Ziaei, N., Rezaiatmand, Z., and Ranjbar, M. (2014). Study of aluminum toxicity on photosynthetic pigment, soluble sugars and proline contents in two sunflower varieties. Res. Crop Ecophysiol. 9, 105-113. Available online at: http://journals. khuisf.ac.ir/roce/article-1-42-en.pdf

Conflict of Interest Statement: The authors declare that the research was conducted in the absence of any commercial or financial relationships that could be construed as a potential conflict of interest.

Copyright (C) 2017 Moreno-Alvarado, García-Morales, Trejo-Téllez, HidalgoContreras and Gómez-Merino. This is an open-access article distributed under the terms of the Creative Commons Attribution License (CC BY). The use, distribution or reproduction in other forums is permitted, provided the original author(s) or licensor are credited and that the original publication in this journal is cited, in accordance with accepted academic practice. No use, distribution or reproduction is permitted which does not comply with these terms. 